\title{
Customer Co-Creation and Exploration of Emerging Technologies: The Mediating Role of Managerial Attention and...
}

Article in Long Range Planning · December 2015

DOI: 10.1016/j.lrp.2015.12.019

\section{CITATIONS}

3

3 authors:

\section{Saeed Khanagha}

Erasmus University Rotterdam

12 PUBLICATIONS 68 CITATIONS

SEE PROFILE

\section{Ilan Oshri}

Loughborough University

124 PUBLICATIONS 1,198 CITATIONS

SEE PROFILE
READS

384
H.W. Volberda

Erasmus University Rotterdam

220 PUBLICATIONS $\quad 10,683$ CITATIONS

SEE PROFILE

Some of the authors of this publication are also working on these related projects: 


\title{
Customer Co-Creation and Exploration of Emerging Technologies: The Mediating Role of Managerial Attention and Initiatives
}

\author{
Saeed Khanagha, Henk Volberda, Ilan Oshri
}

Prior research has emphasized the importance of organizational focus on exploratory behavior in response to the emergence of a revolutionary core technology and the associated uncertainties. The question of why some organizations are more successful than others at realizing and reacting to such a need has not yet been fully addressed. In particular, empirical evidence on the effects of customer orientation on the effectiveness of organizational responses to major technological changes is somewhat mixed. We develop and test a theoretical argument in which we emphasize an indirect link between customer involvement in innovation processes and exploratory behavior in emerging technology fields. In so doing, first we illustrate the part played by two managerial factors - attention to the technology and the introduction of non-routine organizational adaptations - in enabling exploratory activities such as experimentation and search for unfamiliar knowledge in a new technology field. Second, we discuss how customer co-creation contributes to both of these managerial factors and, consequently, indirectly stimulates exploratory behavior in these conditions. We provide empirical support for our related theoretical framework by means of six case studies and a survey among 131 companies that were adopting a similar emerging technology; i.e., Cloud computing.

(C) 2015 Published by Elsevier Ltd.

\section{Introduction}

To compete and survive, organizations need to engage not only in activities that are orientated towards efficiency, but also in behavior that is exploratory, such as experimentation, variation and searching for new knowledge (Benner and Tushman, 2003; March, 1991). This requirement is even greater when the business environment becomes more uncertain (Jansen et al., 2006; Kim and Rhee, 2009; Sidhu et al., 2004), and particularly when exogenous shocks or revolutionary transformations such as major technological changes render organizations' core technologies and sources of competitive advantage obsolete (Romanelli and Tushman, 1994; Tushman and Anderson, 1986). Exploratory behavior concerns the discovery of new products, services and markets through enactment and interpretations, rather than planned improvements in performance, and such behavior is known to be crucial for established organizations dealing with a technological change that makes their existing knowledge less useful (McGrath, 2001). Despite the importance of looking for new options in such circumstances, not all organizations overcome the constraints imposed by their existing technological knowledge and expertise. In fact, some organizations attempt, often unwisely, to use the new technology to incrementally improve their existing offerings and thereby salvage their prior investments (Lavie et al., 2010). Existing research has not yet fully revealed the conditions under which organizations opt to focus on exploratory behavior and innovations when reacting to a fundamental change in technology and the associated uncertainties. In order to address this gap, we examine what may be achieved by involving customers throughout the innovation process, often referred to as "customer co-creation". This has been speculated to be an important influence on the search behavior of organizations when facing technological change (Bogers et al., 2010; Rosenkopf and Nerkar, 2001).

The impact of involving customers in the innovation and development processes, particularly when dealing with high degree of uncertainty brought by the emergence of a revolutionary new technology, is controversial and the findings provide a far from clear conclusion. Some scholars have been critical of intensive interaction and reliance on customers' input during innovation process, arguing that it contributes only to incremental and trivial product development activities (Bennett and Cooper, 1979) and myopic R\&D programs (Frosch, 1996); they say that it therefore puts organizations at risk of being held "captive by their customers" and of failing to cope with technological change (Christensen, 1997, 8). Verganti (2009) goes so far as to assert that companies need to forget customer-centered innovation if they wish to achieve breakthroughs because 
radical innovations assume different contexts and user approaches to those than those with which customers are familiar. Others (e.g., Danneels, 2003; Stanley and Narver, 1998) have contested such inferences and argued that being very closely connected to its customers may improve an organization's responsiveness to external triggers. Some empirical research contends that co-creation as a whole contributes positively to exploration and helps organizations to tackle uncertainties (Carbonell et al., 2009) because it allows them to access customer knowledge (Bogers et al., 2010; Hienerth, 2006; Lüthje et al., 2005; Nambisan and Baron, 2010) that may lead to radical innovations (Lüthje and Herstatt, 2004; Lynn et al., 1996; SánchezGonzález et al., 2009). Other studies, however, discuss how customer co-creation may undermine effective exploration in conditions of uncertainty because scarce organizational resources are allocated to intensive relationships and knowledge exchange with external parties that do not necessarily share the same long-term goals (Almirall and Casadesus-Masanell, 2010; Laursen and Salter, 2006). In this contested research landscape, we seek to provide more clarity by examining whether customer co-creation gives rise to a focus on exploratory behavior in organizations when they are responding to a revolutionary technology change and, if so, what the underlying mechanisms are.

In order to address our research questions, we focus on the important role played by senior managers in enabling their often-unprepared organizations to make an effective response to external forces (Eggers and Kaplan, 2009). Existing research on the drivers of exploration has focused largely on conditions of change which imply a certain degree of predictability, rather than abrupt and highly unpredictable revolutionary transformations such as those that follow the emergence of a new core technology (Lavie et al., 2010). As a consequence, a number of persistent and relatively stable senior management related variables such as risk aversion (Lewin et al., 1999) and entrepreneurial style (Covin and Slevin, 1989), the design and composition of management teams (Smith and Tushman, 2005), and demographics and leadership skills (Jansen et al., 2009; Vera and Crossan, 2004) have been put forward as antecedents of exploratory behavior. Based on the argument that responding to a technological change requires an organization to embrace a challenging and often painful process of reorientation (Eggers and Kaplan, 2009), we develop a conceptual framework in which there is an emphasis on the role played by senior managers' cognition and initiatives in enabling exploration in such conditions. We would suggest that these managerial roles are being directly influenced by organizations' customer co-creation strategies and the involvement of customers in innovation processes.

The main contribution of this paper is to the discussions on the antecedents of exploration orientation; in particular, we seek to address the research gap on the drivers of exploratory behavior in response to major technological changes (Lavie et al., 2010). We investigate the unique role of senior managers in the exploratory orientation of organizations facing major technological changes and we examine what effect the co-creation of value has in enabling them to perform such roles. This enables us to address the call for further research on the managerial capabilities that underlie effective organizational response to external change (Helfat and Peteraf, 2014) in the specific context of emerging technologies. We also contribute to the discussions on the role of customer co-creation strategies - and customer orientation in general - in company competitiveness and performance. This relationship has long been a matter of debate and many questions remain unaddressed. We address the little-understood effect of customer-centric innovation on firms' behavior in the early stages of technology and industry lifecycles (Bogers et al., 2010). We provide evidence that customer co-creation strategies influence managers' cognition and behavior and hence make organizations both more inclined to undertake exploration under conditions of uncertainty and more able to do so.

The context of this study is a revolutionary emerging technology, Cloud computing, which is at the top of the list of revolutionary forces in a wide range of industries. We scrutinize how customer co-creation strategy may influence whether companies are able to respond effectively to this wave of change. We discuss two common strategies for embracing Cloud: using it either to make minor improvements in existing offerings or to radically renew their products and services (exploratory innovation). The latter approach enables organizations to redefine the architecture of their solutions and to make better use of the full potential of Cloud. Looking at how companies have responded to Cloud gives us an ideal basis for understanding the reasons why organizations differ in their focus on exploration.

In this paper, we first use the existing literature to identify those drivers of exploratory behavior that are connected to value co-creation and that are currently less well understood in the kind of conditions we have described. We then develop a theoretical framework on the possible relationship between value co-creation and exploration in emerging technology fields, and on the mechanisms that drive such a relationship. To examine and elaborate on our related set of hypotheses, we analyze both qualitative and quantitative data. Using qualitative data is intended to enrich and further clarify the complicated relationship central to this study by providing details and examples. Our quantitative analysis provides statistical evidence concerning the hypothesized relationships. The paper ends with a discussion of the findings and some concluding remarks.

\section{Customer co-creation and innovative behavior by organizations}

Value co-creation can influence the innovative performance of an organization by providing access to product usage data, speeding up the innovation process, improving the quality of the offerings, and enhancing the reputation of a company and the image of its products (Carbonell et al., 2009; Gupta and Wilemon, 1990; Joshi and Sharma, 2004; Lengnick-Hall, 1996; Sawhney et al., 2005; Utterback, 1994). It also helps companies to recognize opportunities for making continuous improvements in their existing products (Grewal et al., 2006; von Hippel, 1988; Xie et al., 2008). Co-creation is suggested to be a precursor of firms' knowledge exchange and combination capacity (Kogut and Zander, 1992; Nahapiet and Ghoshal, 1998; 
Nambisan, 2002) and therefore their responsiveness to environmental dynamism (Baker and Sinkula, 2007; Belderbos et al., 2004; Foss et al., 2011; Nambisan and Baron, 2010). Overall, customer co-creation strategies have been considered to be a source of innovativeness and competitive advantage (e.g., Cook, 2008; Evans and Wolf, 2005; Fey and Birkinshaw, 2005; Prahalad and Ramaswamy, 2004a; von Hippel, 2005). In particular, working with lead users is discussed by a group of scholars as a potential source for breakthrough innovations (Baldwin et al., 2006; Franke and Shah, 2003; Franke et al., 2006).

When it comes to exploratory behavior in response to revolutionary technological changes, the impact of customer cocreation is less clear. Because of their limited knowledge and capabilities compared with expert innovators, customers are likely to provide input that is close to producers' existing knowledge and this then results in innovations that are incremental in nature (Henderson, 1993; Rosenkopf and Nerkar, 2001). Only when there is a strong incentive to adress their particular needs will input from customers perhaps directly trigger attempts at exploratory behavior that may lead to redefined products (von Hippel, 1988, 2005). Even then, engaging with customers to deal with such demands is challenging because of the relationship and coordination costs involved (Almirall and Casadesus-Masanell, 2010) and the incongruent goals of customers and producers (Bowen and Jones, 1986). As contended by Laursen and Salter (2006), searching too extensively for customer knowledge may prove detrimental as it can distract from the task of identifying and allocating resources to areas that will be key in enabling the organization to maintain its competitiveness in response to a major technological change. This is similar to what Christensen (1997) describes as the reasons behind the failure of customer-oriented companies to cope with technological change, namely that they become blind to the real sources and consequences of disruption. The discussions above highlight some of the potential benefits as well as some significant reservations regarding the possible relationship between co-creation strategies and the exploratory behavior of organizations in an emerging technology field.

\section{Exploration in emerging technology fields - the role of senior managers}

Senior managers have a unique role in enabling an organization to respond effectively to technological change (Eggers and Kaplan, 2009; Tushman and Rosenkopf, 1996). Exploring opportunities in an unfamiliar context and under conditions of uncertainty and complexity requires substantial funds and considerable effort on the part of the organization (Helfat and Peteraf, 2014). Organizations need to develop new capabilities. No one plays a more important part in this than senior managers (Maritan, 2001). Moreover, dealing with an emerging technology may require the development of new and complex business models (Teece, 2007), and senior managers are essential in that process (Doz and Kosonen, 2010; McGrath, 2010). Orienting the organization towards exploration mode in such conditions requires a dynamic decision-making process and frequent trade-offs between contrasting and conflicting agendas (Smith et al., 2010). Without the involvement of senior managers, exploration at lower levels of the organizations may backfire, taking the organization in different directions, and perhaps resulting in poorer performance (Coen and Maritan, 2010; Siggelkow and Rivkin, 2006). We now discuss two distinct ways that senior managers play a role in exploration in an emerging field, and also why customer co-creation matters in enabling managers to perform such roles.

\section{Managerial attention and exploratory behavior in emerging fields}

Research on the microfoundations of capabilities emphasizes the role of senior managers' cognition and actions in enabling an effective organizational response to the dynamism in the external environment (Adner and Helfat, 2003; Thomas, 1988; Tushman and Rosenkopf, 1996; Virany et al., 1992). However, the effects of senior managers are not always similar (Hambrick and Quigley, 2014), and there are stories of organizations that have responded to major changes without any notable involvement from their senior managers, or even despite them expressing negative perceptions and disapproval (Augsdorfer, 2005; Grimpe, 2006; Karlsson and Lugn, 2009). Although organizations' engagement with new technologies is not entirely bounded by what their senior managers do, senior managers' cognition and actions have important bearings on the timing and the nature of engagement in a major technological change (Eggers and Kaplan, 2009). In particular, exploratory behavior in an emerging field has certain requirements that, as we will argue next, cannot be realized without senior managers being attentive and making correct interpretations.

Attention can be defined as focused awareness on a subset of available information (Helfat and Peteraf, 2014), for example, information pertaining to a particular emerging technology (Eggers and Kaplan, 2009). Although many members of the organization play some role in scanning the environment and interpreting the changes, the point at which information converges and is interpreted in order to inform organizational action is assumed to be at the top management level (Cho and Hambrick, 2006). In the case of a major technological change, senior managers must notice and stay alert so as to detect the direction of the change and create new opportunities whenever possible (Helfat and Peteraf, 2014). Managers are not equally successful in doing so, because the high levels of uncertainty and embryonic nature of technologies and markets (Day and Schoemaker, 2010) and the complexity caused by the proliferation and diversity of factors and challenges in the environment (Miller and Friesen, 1983; Tan and Litschert, 1994) give rise to cognitive challenges for managers. Hence, organizational responses to a technological change are related to their managers' ability to overcome such cognitive challenges and to correctly interpret the timing, magnitude, and scope of change (Barr, 1998; Cho and Hambrick, 2006; Eggers and Kaplan, 2009; Kaplan et al., 2003; Li et al., 2013; Ocasio, 1997).

The inability of managers to focus their attention on an emerging field of knowledge is detrimental to effective exploration of that field for at least two reasons. First, exploratory behavior in general requires investments that are often substantially 
higher than those needed for efficiency-oriented activities (Grand et al., 2004), and investment requirements tend to be very high in the case of emerging technologies (Soares, 1997). Therefore, when the initiative to engage with a new technology fails to attract the attention of influential managers, the individuals and teams who plan to focus on the new technology won't receive sufficient resources for effective exploration. Additionally, exploring the full scope of opportunities offered by an emerging technology requires resources and expertise beyond what isolated individuals or teams can achieve and calls for cross-team and cross-unit collaboration (Hamilton, 1985; van der Valk et al., 2011). In such circumstances, managerial attention is crucial for enabling organizational alignment and collaboration outside the limits of existing departmental expertise and focus (Taylor and Helfat, 2009) and thereby ensures that the resources and expertise needed for effective experimentation and learning in the new context can be secured. Second, the risk of failure during the exploration of emerging technologies is high (Day and Schoemaker, 2000), and unless senior managers appreciate the value of learning from experimentation, things that do not go strictly to plan will be regarded as deviations and branded as failures (McGrath, 2001). When managers do not appreciate learning, organization will become more focused on low-risk behavior and this situation inevitably deters organizational members from engaging in exploratory behavior and limits the span of search for new knowledge to areas that are close to existing knowledge and expertise.

In short, this discussion highlights why and how attentive managers can have a remarkable effect on enabling effective exploratory behavior in their organizations, and it is therefore reasonable to argue that:

Hypothesis 1. Managerial attention to an emerging technology is positively related to exploratory behavior in that field.

\section{Managerial attention as the link between customer co-creation and exploration}

We discussed why managers' attentiveness to an emerging technology and its implications results in there being more inclination and capability within the organization for exploratory behavior in that field. Indeed, the role of attention has long been emphasized by some authors as one of the central issues in the management of innovation (e.g. Hurley and Hult, 1998; Van De Ven, 1986). This then raises the question of how attention can be managed effectively within the organization - or, in particular, what drives managers to focus on the development of innovative ideas which are very different from the organization's standard ways of working (Van De Ven, 1986). Customer co-creation can play an important role in forming and directing managerial attention. Normann $(1977,84)$ observed that successful organizations, driven by a desire to understand advanced market needs, are not only close to their customers, but also "search out and focus on their most demanding customers". Similarly, von Hippel and his colleagues (1999) discuss how interactions with lead users may help the organization to be more aware of and responsive to major shifts and trends in the market. Such strategies are believed to stimulate managers to pay attention to changing environments and customer needs (Van De Ven, 1986).

Although customers may be unable to provide details of forthcoming breakthroughs (see Verganti, 2009), customer cocreation may allow an organization to scratch beneath the surface of changes and emerging trends in the markets and, by that, be more capable of spotting the emerging market shifts early on. By increasing the bandwidth for sending vital information to senior managers and enabling them to sense faint signals that might otherwise not be picked up, customer cocreation therefore increases managerial focus and attention on the most important changes in the market (Thomke and von Hippel, 2002). Especially, when competing trends and internal and external pressures occupy the attentional bandwidth of senior managers, customer inputs may serve as important levers for creating a sense of urgency in responding to revolutionary forces in the market (Brown and Eisenhardt, 1997; Parasuraman et al., 1985). Without face-to-face interactions with key customers during innovation efforts, managers may fail to seize the opportunities for understanding and responding to the emerging shifts in what customers need (Lettl et al., 2006). Co-creation with customers is thus likely to improve the alignment between senior management's perceptions and shifts in markets and heighten their attentiveness to the consequences of a major technological change. These arguments become particularly relevant when a new technology emerges and the industry enters an era of ferment in which changes in the markets and customer become the rule rather than the exception (Day and Schoemaker, 2000; Jansen et al., 2006; Tether, 2002).

The attentiveness that follows customer co-creation may give rise to the change being interpreted as an opportunity, and this kind of interpretation is known to be an important stimulus for exploratory behavior. It is worth noting that managers can perceive ambiguous environmental forces, such as those that result from the emergence of a new technology, in different ways; some may see them as opportunities and others as threats (Barreto and Patient, 2012). These perceptions vary between organizational decision-makers according to individuals' existing attentional drivers - that is, the social, economic, cultural, or cognitive factors that shape how managers allocate their time, effort, and attentional focus (Barnett, 2008; Ocasio, 1997). Financial dependence on existing technologies and revenue streams from customers is one of the key factors that influence the "opportunity" versus "threat" perception of managers (Gilbert, 2005). When investment in a new technology has a cannibalizing effect on existing sources of revenue, a sense of threat will become prevalent, reducing the tendency to experiment and to seek exploratory innovations (Ross and Staw, 1993). In contrast, working with customers in the innovation process reduces the potential risks by securing a degree of commitment from the customers involved concerning the potential market for subsequent offerings. Hence, the perception of opportunity is likely to be greater when customers are involved in and committed to the innovative activities, and this increases the tendency for an organization to engage in experimentation and divergent thinking (Gilbert, 2005). As a result, customer co-creation strategies influence the 
opportunity perception of managers, their locus of search, and the intensity of that search (Li et al., 2013), and therefore their tendency to engage in exploratory behavior when needed. Based on this reasoning, we argue:

Hypothesis 2. Managerial attention to an emerging technology mediates the relationship between customer co-creation and exploratory behavior in that field.

\section{Managerial initiatives and exploratory behavior in emerging fields}

Prior research discusses organizational antecedents of exploration (see Lavie et al., 2010, for a comprehensive review), but those discussions are often limited to moderate levels of dynamicity and do not address the major changes that come with rise of an emerging technology (Lavie et al., 2010). This tends to leave us with a rather static view of the fit between organizational characteristics (such as structure, culture, and routines) and the desired balance between the exploratory and efficiency-oriented activities of the organization. However, understanding the determinants of competitiveness in highly dynamic environments mandates that one should go beyond such static views and gain a deeper understanding of the dynamic nature of strategic change process (Ansari et al., 2010; Zajac et al., 2000). A dynamic approach implies the need for implementation of new managerial practices, processes, and structures through a process of domestication, reconfiguration and reconstitution to contextualize them within specific organizational environments (Ansari et al., 2014). Such a need is more relevant for exploring an unfamiliar and fundamentally different technology area that requires an organization to break free from persistent and inflexible organizational routines that are tightly aligned with existing technologies and markets (Benner and Tushman, 2001; Burgelman, 1994; Gilbert, 2005; Schreyögg and Sydow, 2011) while maintaining the efficiency of the ongoing businesses. Overturning these routines or introducing new ones with sufficient pace and scope to match the major changes taking place within the environment is a challenging task for managers, and requires considerable effort (Siggelkow, 2001; Teece et al., 1997). In such conditions, managerial initiatives become crucial in order to enable exploratory behavior and to align the internal organization with the external changes (Adner and Helfat, 2003; Lavie, 2006).

Although the managerial initiatives needed to stimulate and foster exploration point toward the common goal (i.e., enabling search for and identification, assimilation and use of knowledge of the emerging technology), the required adaptations are diverse in nature. One of the important aspects of such initiatives concerns changes in the organizational structure; for example, this might involve increasing the autonomy of the innovation teams (Birkinshaw et al., 2012) or creating new organizational linkages (Jansen et al., 2010; Lavie et al., 2010; Taylor and Helfat, 2009) that enhance cross-functional collaboration and the connections between different organizational units in accordance with the context and requirements of the technological change (Jansen et al., 2009). Opting for a generic organizational form - for example, a dedicated organizational unit for exploration - is unlikely to fulfill the structural requirements of exploration in a rapidly changing and turbulent environment. In fact, competing and contradictory requirements for running existing businesses, preserving existing resources, collaborating across units, and nurturing the exclusive requirements of exploratory activities mean that more complex structural approaches are needed; these might entail either alternating between different structural forms or combining them in a repetitive manner (see Boumgarden et al., 2012; Gulati and Puranam, 2009; Siggelkow and Levinthal, 2003).

Moreover, to help the organization explore an emerging technology effectively, managers need to develop new procedures that are in keeping with the organization's rapidly changing environment (Brown and Eisenhardt, 1997). They need to ensure that there are processes in place that enable them to receive new knowledge and to mobilize resources so that they can act upon their decisions (Boeker, 1997; Virany et al., 1992). At an operational level, and in order to probe the possibilities for innovation in the new technology context, managers have to focus on developing routines and processes that nurture experimentation and allow for trial-and-error learning (Thomke, 2003). This has important implications for product development and innovation processes that are often not attuned to experimental learning. Another area affected is incentive systems in the organization that often tend to reward financial payback and shareholder value creation (Kaplan and Henderson, 2005). However, as contended by McGrath (2001), exploration requires acceptance and an open attitude towards failure as a means for learning in unfamiliar fields. This implies a need to develop new incentive and reward systems. Related to this is a general need to reduce the degree of formalization - that is, written rules and procedures - in order to accommodate exploration (Jansen et al., 2006).

The discussion above highlights instances of new structures, processes, and practices that are crucial precursors to exploration in emerging fields. These can be brought about by managerial initiatives or management innovation defined as the introduction of new systems, structures, and processes to further organizational goals (Birkinshaw et al., 2008; Heyden et al., 2015). The novelty of such initiatives may be relative to the world, to the specific market, or to the firm (Vaccaro et al., 2012). Introducing these managerial initiatives helps the organization to overcome the rigidities that hinder exploration by stimulating empowerment, flexibility, experimental processes and mentalities across organizational units (Birkinshaw et al., 2008; Damanpour, 1991; Jansen et al., 2006; McGrath and MacMillan, 2000; Veryzer, 1998). Nevertheless, organizations are not all equally capable of realizing such managerial initiatives (Fleming, 2002; Gebauer, 2011; Mol and Birkinshaw, 2014), and it is therefore reasonable to argue that:

Hypothesis 3. The ability to introduce new managerial initiatives will be positively related to exploratory behavior in emerging technology fields. 


\section{Managerial initiatives as the link between customer co-creation and exploration}

We discussed how managerial initiatives and non-routine responses to the environmental triggers are crucial for overcoming rigidities and catering to the requirements of an emerging technology. But it is important to know where such ability for introducing managerial initiatives comes from. In other words, what makes some organizations more capable of introducing new systems, structures, and processes required for exploring an emerging technology field? Prior research suggests that in dynamic, complex and fundamentally unpredictable environments, the effective introduction of managerial initiatives is dependent on having a flexible organization that can be adapted in response to competitive forces (Volberda, 1996). A few studies that thus far have empirically investigated the antecedents of organizational adaptability have confirmed the important enabling role of both internal agents such as transformational leaders (Vaccaro et al., 2012) and external agents such as consultants, gurus, and other organizations (Mol and Birkinshaw, 2014). There are theoretical discussions that highlight orientation towards customers as a key precursor of organizational flexibility and ability for introducing managerial initiatives. Volberda (1996), for example, contends that the largest potential for flexibility comes with an organizational setting in which numerous direct client contacts are secured and which facilitates a quick response to changes in customer demand. Similarly, Bahrami (1996) suggests that a common characteristic of flexible and organizationally adaptable firms is their emphasis on close interactions with markets and customers. More recent empirical studies confirm that co-creation with customers bring about new organizational practices and managerial initiatives that, in turn, give rise to a firm's ability to identify and assimilate (Foss et al., 2011) and also to commercialize (Foss et al., 2013) external knowledge.

Customer co-creation has the potential to increase the organization's flexibility and its ability to introduce managerial initiatives in several specific ways. Successful use of co-creation strategies requires a major overhaul of a company's traditional governance systems and its organizational structures (Prahalad and Ramaswamy, 2004a) and brings a wide range of new processes and procedures that differ markedly from the organization's conventional routines (Piller and Walcher, 2006). The changes include moving away from traditional policies on intellectual property, establishing new incentive systems, continuous communication and feedback loops, and new strategies for overcoming internal resistance (Hienerth et al., 2011) as well as new organizational structures and processes for innovation and product development (Foss et al., 2011; Lewin et al., 2011). As such, a persistent focus on co-creation strategies engenders a continuous process of learning from and adapting to customers' knowledge (Peeters et al., 2014). The continuity of this learning process arguably gives rise to organizational flexibility and stimulates a greater ability to introduce further managerial initiatives revolving around knowledge absorption and innovation activities, albeit not necessarily related to customer co-creation.

The reason why customer co-creation may make organizations more capable of introducing initiatives needed for exploring an emerging technology can be understood by looking at the correspondence between knowledge characteristics and effectiveness of organizational practices (for a discussion, see Birkinshaw et al., 2002, and Birkinshaw, 2002). Customerrelated knowledge is deeply rooted in customers' context and experiences and is very difficult to encode into explicit terms (Lüthje and Herstatt, 2004). Similarly, the body of knowledge on an emerging technology tends to be embryonic and shared by numerous players from diverse backgrounds (Day and Schoemaker, 2000). Both types of knowledge resemble what Winter (1987) refers to as tacit, hard-to-observe, complex, and system-dependent knowledge and both require outward looking processes and practices to recognize, assimilate, and utilize the knowledge that resides outside the organizational boundaries. For example, co-creation brings processes for communication and interaction with customers and for integration of the subsequent knowledge (Bowen, 1986; Payne et al., 2009; Prahalad and Ramaswamy, 2004b; von Hippel, 2005) and the adoption of flexible structures and rules that facilitate those activities (Campbell et al., 2003; Koka and Prescott, 2002; O'Hern and Rindfleisch, 2010). Exploration of an emerging technology also needs communication and knowledge exchange with a wide range of industry actors and structural and other organizational provision to support acquisition and assimilation of knowledge held by academic and research institutions, competitors, suppliers, and other stakeholders (Day and Schoemaker; 2000; Rothaermel and Hess, 2007). As another example, co-creation strategies urge organizations to delegate responsibility to employees, and empower staff to make decisions with regard to innovation activities; they need to be encouraged to go beyond the limits of existing knowledge (Foss et al., 2011) and to transfer the subsequent knowledge to decisionmakers (von Hippel, 2005). Likewise, exploration in emerging fields requires certain groups of employees to be empowered to experiment and learn from their failures and to transfer such learning outcomes to decision-makers and other parts of the organization (McGrath, 2001). From the perspective of innovation processes, both customer co-creation (Karpen et al., 2011; O'Hern and Rindfleisch, 2010) and exploration of emerging technologies (Day and Schoemaker, 2000; Smith and Lewis, 2011) come with a need for iterative processes of innovation and frequent feedback loops and to move away from using inward-looking stage-gate or waterfall processes. As such, customer co-creation stimulates the introduction of new systems, structures, and processes inherently similar to the adaptations required for the exploration of emerging technologies. The expected outcome is that organizations that engage in customer co-creation, through a learning process, will become more skilled at devising the required organizational adaptations that, as a whole, enable an outward-looking process of knowledge search and exploration with characteristics that are essential for dealing with major technological changes. We therefore argue that:

Hypothesis 4. The ability to introduce new managerial initiatives mediates the relationship between customer co-creation and exploratory behavior in emerging technology fields. 


\section{Research context}

Cloud computing represents a revolutionary technology change that is expected to transform a wide range of industries and businesses. In a 2013 executive survey, Cloud and mobile technologies were by some distance top of the list of technologies considered indispensable for the next generation of products (KPMG, 2013). In simple terms, Cloud computing offers a means of allowing convenient, on-demand network access to a shared pool of configurable computing resources (e.g., networks, servers, storage, applications, and services) that can be procured rapidly and released with minimal management effort or service provider interaction (Zhang et al., 2010). Companies no longer need to be concerned about either overproviding for a service which might not prove as popular as predicted and might therefore waste precious resources, or under-providing for one that becomes hugely popular, leading them to miss out on potential customers and revenue. This elasticity of resources, where companies do not have to pay a premium for large scale, is unprecedented in the history of information and communication technologies (Armbrust et al., 2009).

Cloud computing represents a convergence of two major trends in information technology: IT efficiency through highly scalable hardware and software resources, and business agility through the rapid deployment of mobile interactive applications that respond in real time to user requirements and the use of computer-intensive business analytics (Marston et al., 2011; Smith, 2009). In addition to these direct effects, Cloud is believed to bring revolutionary possibilities to a range of industries and markets. Cloud-based platforms can bring together disparate groups of people and enable them to collaborate and share resources, information and processes. The ability to store huge amounts of data on customers gives companies a valuable asset that they could also potentially use to boost radical innovations in their offerings and business models. Moreover, companies can make customer-related data even more valuable if they can find a way to enable two-way communication with their customers, or if they use other technologies such as business analytics and Big Data to explore totally new ways of value generation (Berman et al., 2012). Cloud has the power to enable a radical redefinition of businesses - for example, by turning vendors of infrastructure equipment into service providers. Industry experts believe that realizing the benefits of Cloud entails a fundamental reorientation of businesses that goes beyond efficiency-oriented and incremental use of Cloud in legacy systems.

\section{Data and method}

We applied a multi-method approach to examine the theoretical model that was presented in the previous sections. Using a multi-method approach is useful for gaining an in-depth understanding of a phenomenon (Hodson, 2004). An important advantage of this approach is that it provides a means to confirm or disconfirm our hypotheses and to assess and corroborate evidence from multiple angles, so enhancing theoretical validity (Creswell, 2008). Combining strengths from both quantitative and qualitative techniques of data collection and analysis is particularly advantageous for triangulating results and enhancing the rigor and robustness of the research (Creswell, 2008).

The empirical data collection started with a qualitative study, a multiple case study of six firms we used to gain a more thorough understanding of the managerial roles of relevance for exploratory behavior, and to assess their relationship with co-creation strategies. In this phase, we first conducted exploratory interviews with Cloud computing experts in order to gain further understanding of the Cloud computing in relation to our theoretical framework. Next, we selected six companies affected more or less similarly by Cloud as an emerging phenomenon, but have different approaches to exploring the opportunities that this technology offers. We selected three companies with a more exploratory focus and three companies with a lower level of Cloud exploratory activities. In total, 22 individuals participated in this phase of data collection; a summary of participants and their positions can be found in Table 1 . The case studies were developed using semistructured interviews; these allowed a flexible interview process, enabling the researcher to pick up and ask follow-up questions to statements by interviewees that were of particular interest for the study. All interview results were analyzed and coded to form clusters of statements relating to connected topics. Those statements coded to be directly linked to one of the four hypotheses were summarized in a structured manner. Interviews were guided by semi-structured interview protocols to stimulate sufficient information richness of the responses (see Appendix A). This approach further served to increase reliability of the responses (Yin, 2009). Interviews lasted between 45 minutes and an hour and 15 minutes. Respondents were first asked to describe their role with respect to their company's Cloud computing activities, and subsequently indicate their understanding of Cloud as a phenomenon. This was done to crosscheck for individual differences in definitions, in order to avoid possible negative effects for the coherence of the answers. All interviews were recorded and subsequently transcribed, resulting in approximately 230 pages of analyzable interview material. Prior to further analysis, the transcripts were sent to all interviewees for feedback and approval.

Next, we performed an online survey among Dutch users of Cloud computing to test the proposed theoretical framework. Through collaboration and interaction with a large professional Cloud computing community (962 IT companies in total) in the Netherlands, we identified a sample of 299 companies of this population with representatives available for external contacts. After initial invitations and a reminder, 131 completed responses were collected, which represents $43.8 \%$ of the identified sub-group of the population. The respondents had an average tenure of 6.76 years (S.D. $=5.99$ ). $25.1 \%$ of the companies represented had 48 or fewer employees, 50.3\% had 160 employees or fewer, and 79.0\% had 3,000 employees or fewer. To control for varying responses between early and late respondents, model variables were compared for early and late respondents. T-tests did not reveal any significant differences $(\mathrm{p}<0.05)$. Following the approach applied by Jansen 
Table 1

Descriptions of cases and informants

\begin{tabular}{|c|c|c|c|c|}
\hline Firm & Number of employees & Number of informants & Position of informants & Exploratory focus \\
\hline $\mathrm{A} 1$ & 350 & 4 & $\begin{array}{l}\text { CEO } \\
\text { Manager, Infrastructure } \\
\text { Manager, End-user Automation } \\
\text { Manager, Strategy \& Innovation }\end{array}$ & No \\
\hline $\mathrm{A} 2$ & 35 & 4 & $\begin{array}{l}\text { Product Manager } \\
\text { Account Manager } \\
\text { Project Manager } \\
\text { Lead Developer }\end{array}$ & $x$ \\
\hline A3 & 290 & 3 & $\begin{array}{l}\text { CIO-Manager ICT } \\
\text { Manager Customer Service }\end{array}$ & No \\
\hline B1 & 2,200 & 4 & $\begin{array}{l}\text { Product Marketing Director } \\
\text { Managing Director } \\
\text { Customer Care Manager } \\
\text { Technology Director }\end{array}$ & Yes \\
\hline B2 & 610 & 3 & $\begin{array}{l}\text { President } \\
\text { Chief Strategy Officer } \\
\text { Director Sales \& Marketing }\end{array}$ & Yes \\
\hline B3 & 26,000 & 4 & $\begin{array}{l}\text { Manager Cloud Services } \\
\text { Innovation Manager Cloud Businesses } \\
\text { Director Cloud } \\
\text { Senior Manager }\end{array}$ & Yes \\
\hline
\end{tabular}

et al. (2005), we controlled for single-source bias by identifying second respondents from 20 companies, and first and second respondents were compared, but no significant differences $(\mathrm{p}<0.05)$ were found. To control for non-response bias, company size for respondents and non-respondents was compared; here also no significant differences were found $(\mathrm{p}<0.05)$. To control for non-response bias, company size for respondents and non-respondents was compared; here also there were no significant differences $(\mathrm{p}<0.05)$.

\section{Measures}

\section{Co-creation}

Prahalad and Ramaswamy (2004b) provided the four building blocks of co-creation: dialogue, access, transparency and risk. Based on this work, O'Hern and Rindfleisch (2010) defined four distinct types of customer co-creation: 1) collaborating, 2) tinkering, 3) co-designing, and 4) submitting. Collaborating was defined as a process in which customers have the power to collectively develop and improve the core components and underlying structure of a new product; tinkering was defined as a process in which customers make modifications to a commercially available product and some of these modifications are incorporated into subsequent product releases. Co-designing was defined as a process in which a relatively small group of customers provides a firm with most of its new product content or designs, and a larger group of customers helps select which content or designs the firm should adopt. Submitting was defined as a process in which customers communicate ideas for new product offerings directly to a firm.

We combined these four measures of co-creation with the relationship learning scale developed by Selnes and Sallis (2003). A seven-item scale was developed $(\alpha=0.89)$, asking to what extent the respondents agreed with the following statements: (1) they collaborate with customers to collectively improve or develop new products/services, (2) their customers directly communicate ideas for new product/service offerings to their firm, (3) they share information with customers in a twoway communication to make their product offerings more valuable, (4) customers' inputs are used to determine which products/ services should be offered/pursued further by the firm, (5) they collaborate with customers to come up with solutions for problems relating to their product offerings, (6) they collaborate with customers to track changes in consumer needs, preferences and behavior, and (7) their relationship with external parties/customers has resulted in actual new/improved products or services.

\section{Managerial initiatives}

The Management Innovation scale developed by Vaccaro et al. (2012) was used to measure the tendency of the organizations to introduce new systems, processes, and practices. Following the definition and insights provided by Birkinshaw and his colleagues (2008), this scale measures changes in six organizational areas: rules and procedures, employees' tasks and functions, management systems, compensation policy, the intra- and inter-departmental communication structure, and organizational structure. This construct captures a general capacity in the organization for introducing non-routine solutions when routine practices prove to be ineffective. The resulting six-item scale for management innovation $(\alpha=0.91)$ was used. 


\section{Managerial attention}

Following several prior studies that have used frequency of references to major discontinuities in formal communications as a measure of management cognition (Barr, 1998; Eggers and Kaplan, 2009; Gerdes, 2003; Kaplan, 2008; Kaplan et al., 2013; Maula et al., 2012; Osborne et al., 2001; Schnatterly, 2003), we asked respondents to report, using a Likert scale, the degree to which Cloud computing was being referred to by senior managers in internal and external communications (such as annual reports, exhibitions, internal speeches, etc.). We also asked whether the respondents believed their senior managers considered Cloud to be a strategic priority for their organization. Rather than asking about "emerging technologies" in general, we asked specifically about Cloud computing to ensure correct interpretation by the respondents and the accuracy of their responses. The resulting three-item measure for managerial attention $(\alpha=0.85)$ reflects the degree to which senior managers perceived and communicated Cloud computing as one of the strategic priorities for their organization. We used company publications and reports, press news, and senior management letters and communications in the company websites to verify the validity of self-reporting items on managerial attention. We scored indications of senior management involvement in Cloud from each of these three sources into three categories, Low, Medium, and High, and calculated an average score on this measure for managerial attention. Contrasting these scores with those provided on the selfreported scale indicated a high degree of correlation between the two measures $(r=0.53, \rho<0.001)$.

\section{Exploratory innovation}

This construct aims to measure whether the companies are attempting to use Cloud to redefine their offerings beyond incremental innovations and efficiency-oriented activities. To measure exploratory behavior in the Cloud context we used the scale developed by Jansen et al. (2006). It captures whether organizations seeks deviation from existing knowledge and pursue radical innovations for emerging customers or markets. The respondents were asked about the extent to which: (1) the organization accepts demands that go beyond existing products and services; (2) they invent new products and services; (3) they experiment with new products and services in their local market; (4) they commercialize products and services that are completely new to the firm; (5) they utilize new opportunities in new markets; (6) they use new distribution channels; and (7) they search for and approach new clients in new markets. We averaged the items to create a composite index for exploratory innovation $(\alpha=0.93)$. Rather than asking about exploratory behavior in the context of "emerging technologies" in general, we asked specifically about their activities in the context of Cloud computing to ensure correct interpretation by the respondents and the accuracy of their responses.

\section{Control variables}

In order to account for potential alternative explanations, several control variables were included. As several studies have claimed that the size of a company may influence its innovation outcomes since a larger company may have more resources but may also lack the flexibility to explore (e.g., Pierce and Delbecq, 1977), we included the natural logarithm of the number of full-time employees within the organization to account for firm size. Additionally, the role of the company in the Cloud computing value chain is likely to have implications for the company's orientation towards exploratory innovation. Four main types of companies are identifiable in our population, namely Cloud providers (52\%), Cloud brokers (14\%), Cloud buyers (13\%), and Cloud enablers/consultants (21\%). These categories are known by the industry players and they were able to identify themselves in one of these four categories. While each of these companies may use Cloud computing in both exploratory and exploitative ways, we controlled for their roles in the statistical model. Moreover, given the existing empirical support for the effect of a match between product-market strategy and business models on a firm's performance (Zott and Amit, 2008), we controlled for the effects of the firm's strategy in relation to Cloud computing. In so doing, we distinguish between companies who indicated that they consider Cloud as a means to wither increase their operational efficiency (20\%) or serve existing markets in a better way (18\%) (defensive market strategy) and those who indicate that they are planning to use it either to expand in existing markets (32\%) or enter totally new markets (32\%) (aggressive strategy).

In order to control for potential endogeneity issue, we added a 2-item instrumental variables namely intrinsic motivation, adopted from the work by Cole and his colleagues (2012), which affect co-creation, and is not correlated with managerial attention and managerial initiatives. These two items measure whether the organizations' member "feel energetic in their job" and if they "are ready to act at any given moment".

\section{Qualitative analysis}

We analyzed the qualitative data to shed light on the components of the theoretical framework and hypothesized relationships. Our focus was first to identify and clarify what we previously discussed as managerial roles that underlie exploratory behavior in the earlier phases of a major technological change. Second, we investigated the customer co-creation strategies of each focal company in connection with the consequences of the identified managerial roles. Potential company cases for this research were identified through exploratory interviews with industry experts and by asking them to specify 
Table 2

Summary of findings from qualitative analysis

\begin{tabular}{|c|c|c|c|c|c|c|c|}
\hline \multirow[t]{2}{*}{ Variables of interest } & \multicolumn{6}{|c|}{ Case study companies } & \multirow[t]{2}{*}{ Indications } \\
\hline & A1 & A2 & A3 & B1 & B2 & B3 & \\
\hline Exploratory innovation & $凶$ & 凶 & $凶$ & $\nabla$ & $\nabla$ & $\nabla$ & $\begin{array}{l}\text { Focus on developing radically new offerings and services } \\
\text { Redefining the architecture of the company's products and services } \\
\text { Searching for and utilizing new markets, channels, and business models } \\
\text { Experimentation with new offerings in pilot markets }\end{array}$ \\
\hline Managerial attention & 0 & D & 0 & - & $\bullet$ & $\bullet$ & $\begin{array}{l}\text { Having the CEO or a board member as the driver or sponsor of Cloud initiative } \\
\text { References to Cloud in formal and informal conversation }\end{array}$ \\
\hline Managerial initiatives & D & $\bigcirc$ & O & $\bullet$ & D & ○ & $\begin{array}{l}\text { Delegation of responsibility to innovation teams } \\
\text { New structures for linking cross-functional innovation activities } \\
\text { Incentive systems to support the incorporation of customer input } \\
\text { Procedures to ensure customer involvement in the innovation process }\end{array}$ \\
\hline Customer co-creation & D & $\bigcirc$ & $\mathrm{O}$ & - & D & $\bullet$ & $\begin{array}{l}\text { Having customers as partners } \\
\text { Formal involvement of customers in the early stages of the innovation process }\end{array}$ \\
\hline
\end{tabular}

$\square$ : Presence of variable; 囚: Absence of variable; ○: Low; $\mathbf{~ : ~ M e d i u m ; ~ \bullet : ~ H i g h . ~}$

companies with contrasting approaches to adopting Cloud computing. Unlike deductive studies based on random samples, and in line with the theory-building purpose of this stage of the study, the six companies were selected based on their expected contribution to the building of theory (Eisenhardt, 1989). We included "polar-types" in the sample as this is known to be a powerful approach for clarifying patterns and relationships within the data (Eisenhardt and Graebner, 2007). The theoretical sampling strategy that guided the selection of the cases was to choose six companies that shared important characteristics but at the same time differed significantly in the key construct of the study: exploratory behavior in response to the emergence of Cloud computing. The companies were all headquartered in northern Europe, active in the same industry (IT), and clearly affected by and involved in Cloud computing. Table 1 provides more details of the six cases and informants. Table 2 gives examples of what we considered to be indications of exploratory behavior as well as other key constructs of this study.

\section{Managerial enablers of exploratory behavior in the Cloud context}

A recurrent observation during the qualitative phase was the role of managers in setting the direction of the Cloud activities within the organization. The companies with a prominent focus on exploratory activities provided clear indications of what part managers played within the organization's overall focus on using Cloud to go beyond their existing goals and plans. All of these companies had a CEO or other board members who were prime advocates of Cloud initiatives. According to the interviewees, this involvement of senior managers was instrumental for the Cloud initiative in a number of ways. Firstly, they found it much easier to secure the resources they needed, and were thus able to experiment and learn through development activities. Secondly, those who were driving Cloud initiatives did not experience much resistance from other members of the organization when attempting to utilize the Cloud in ways that could potentially overturn their existing offerings and products. Senior managers were usually mentioned as the ones who created an exploratory focus in the organization. As one of the key individuals driving Cloud initiatives said: “[Our new senior manager] was very disappointed with [our progress with] Cloud [...] she was seeing the industry progressing very quickly and we were kind of lagging behind. So, basically, she gave the mandate to create what is now our Cloud program."

In contrast, difficulties in securing resources and overcoming resistance in the organization were far more evident in the three companies with a less exploratory focus. In these organizations, because the managers did not support Cloud as a strategic priority, or at least did not communicate any such priority through formal and informal means, only a few employees allocated significant amounts of time to exploration, mostly because of their personal interest in it.

We observed that, in the exploration-focused organizations, senior managers paid attention not merely by providing general directions but also by becoming intensely involved in the detail of the activities of those dealing with the emerging technology. One of the informants described this involvement as follows: "The CEO is personally involved in what we are doing [on Cloud]. That's pretty remarkable for a relatively small department."

According to the case studies, the three exploration-oriented organizations had fewer challenges in introducing the adaptation needed for exploratory activities under conditions of uncertainty. These initiatives included temporary organizations and linkages to accelerate and facilitate exploration, mechanisms to make use of unfamiliar information and ideas, new incentive schemes for innovations that would not generate revenues in the short-run, and so on. Conversely, in the second group of companies that had lower levels of exploratory activities, we observed that they found it more difficult to make any change in the organization, or to introduce managerial initiatives of the kind that are essential for experimentation and learning in the Cloud context, and that have a focus on long-term benefits for the organization.

In the interviews, several informants from exploration-oriented organizations discussed how new managerial initiatives were supporting their exploration in the emerging technology field. This support occurred in a number of ways. For example, new initiatives facilitated collaboration across organizational functions and technical disciplines. In the case of 
Cloud, close collaboration between sales and front-line employees, technical staff, and business and strategy people was crucial for enabling exploratory activities. Having structures and processes in place that enabled and facilitated crossfunction collaboration fulfilled this requirement.

\section{The effect of customer co-creation}

The next step in the development of our theoretical framework concerns the origin of the managerial attention and initiatives that enable exploration in an emerging technology context. In this stage, we analyzed the data in the light of prior research findings in order to discover whether customer co-creation and exploration in emerging fields are indeed linked. We also investigated the underlying mechanisms of such a relationship by looking at how customer co-creation is related to attentiveness to an emerging wave of change and to the organization's tendency and ability to introduce and implement exploration-oriented initiatives. What was common to the exploration-focused companies was their relationship with external parties, particularly with their customers. These companies clearly had a greater tendency to work with their customers on a partnership basis and to use customer input in their innovation processes to a large extent. In contrast, the other group of companies had a stronger focus on internally driven R\&D and their relationships with customers were less of a partnership in nature. Further investigation suggested that in the companies we studied this kind of customer focus plays an important part in making managers aware of the possibilities offered by Cloud and in encouraging initiatives designed to exploit it.

The group of organizations which were less focused on customer interactions and relied more on internal sources in their innovation process regarded Cloud as likely to have a less radical impact and were consequently more inclined to use Cloud merely as a means to improve their existing offerings. In contrast, the decision-makers in companies that had closer relationships with buyers of IT services had a different perception in accordance with their greater understanding of customer values. This perception guided them towards a radical reconsideration of the logic and architecture of their product and service offerings. Although both groups of supplier companies were more or less similarly affected by the potential devaluation of their existing offerings and competencies, those with a stronger customer focus were indicating a deeper understanding of the shifts in customers' expectations of IT solutions and offerings. During the interviews, it was repeatedly said that senior managers or other key employees had realized the importance of Cloud during interactions with their counterparts in client companies and this realization had greatly influenced the objectives of their Cloud initiative. For this group of companies, input from the customer side was typically prioritized over internal conversations and was thus more powerful in terms of attracting managers' attention. Therefore, when customers indicated a desire for Cloud to be considered in future offerings, a customer-oriented company would prioritize a preference of this kind, even when it was not in complete alignment with existing plans. In one of the cases, the company started the Cloud initiative with an exploitation focus, but through interaction with customers their senior managers recognized the need to reorient the initiative towards exploration. It was also a common feature that attentive senior managers had close interactions with a number of strategic customers who saw the Cloud as a game-changing phenomenon and expected their supplier companies to respond in a way that was in line with their vision.

In addition to making senior managers more attentive and involved, customer co-creation was cited by the explorationfocused organizations in our study as an important reason why they needed systems that allowed them to experiment with Cloud. We asked about the systems, structures, processes, and practices that they used for this experimentation and about the origins of such initiatives. The responses referred quite frequently to the way they worked with their customers in the partnership relationship and how they adapted the organization on a permanent or temporary basis to ensure the inclusion of customer input in the innovation process. Such changes were often in the form of reorganizing in response to a shift in the market or in customer demands. The empowerment of decentralized teams that work with customers was an essential pillar in such adaptations. Such practices relied on delegation of responsibility to ensure that customer input would be used effectively and would not get lost in the hierarchy or in competition with other internal matters. The interviewees also mentioned how they were used to experimental practices for product development and innovation processes when working on joint projects with customers. For example, turning customer input into innovation required structures, processes, and communication channels that cut across the various functions of the organization. When dealing with Cloud as an emerging technology, such arrangements were also key enablers of exploratory activities. For example, the experimental processes that were crucial for exploratory activities were also essential tools for innovating with customers. One of the informants explained it as follows: “...The customer needs are unknown; we need to face unknown challenges and we must learn and experiment so we can develop a standard process again."

In contrast, organizations that relied primarily on internal sources of knowledge typically did not possess these kinds of experimental tools and processes. As expected, it was apparent in these cases that there was little or no exploratory behavior. Some of the findings are illustrated in Table 2. More examples of such initiatives and representative quotations are presented in Figure 1.

\section{Quantitative analysis}

The data analysis of the quantitative section of this study was performed in two stages. In the first step, a measurement model that describes the relationships among the latent constructs was assessed to determine whether the latent variables were defined appropriately and measured in a consistent manner. In the second step, a combination of 


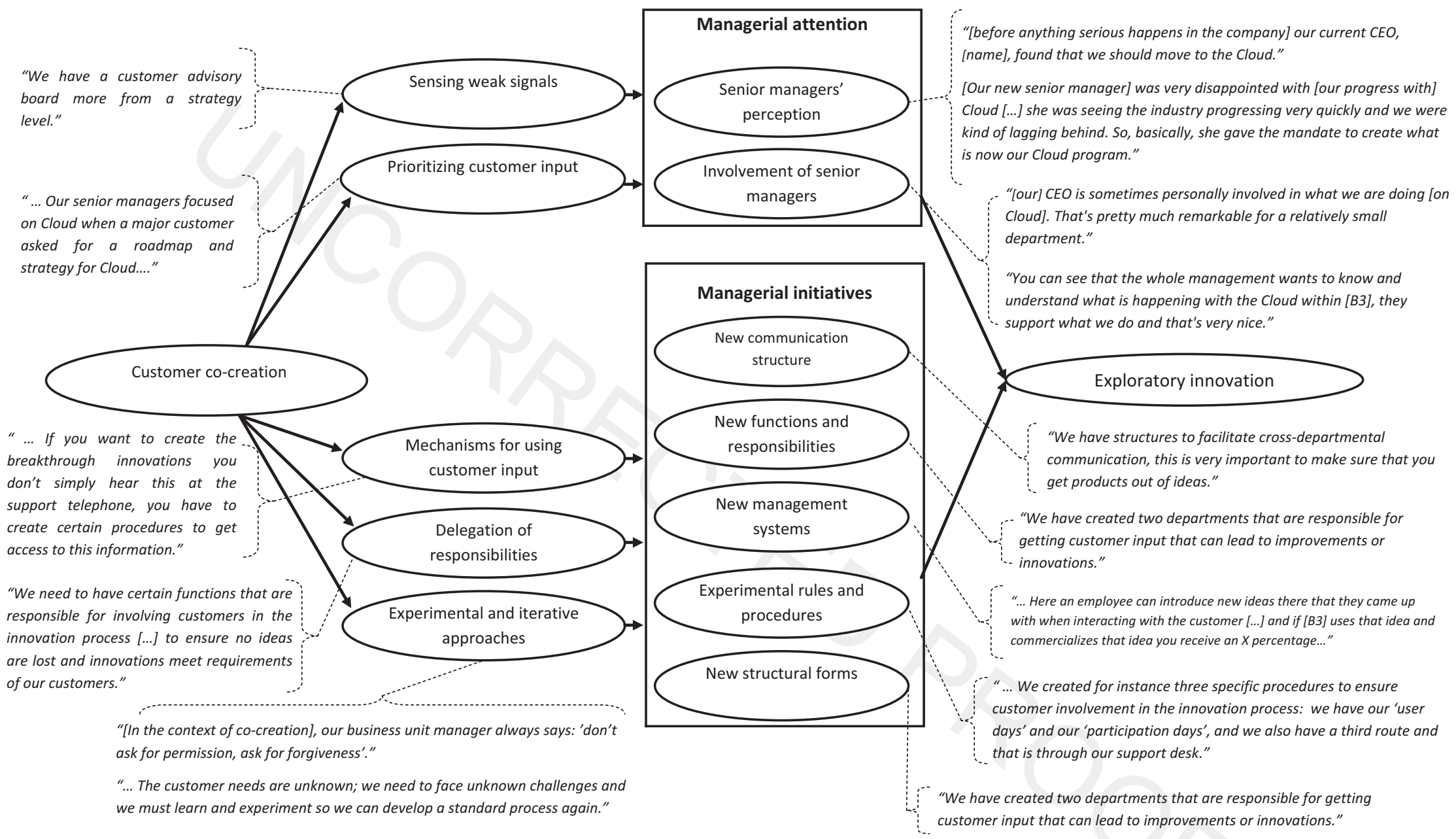

Figure 1. Qualitative data analysis - mechanism underlying the mediating role of managerial attention, with illustrative quotations 
hierarchical regression analysis and structural equation modeling was used to test the hypotheses we had developed in previous sections.

\section{Measurement model}

We conducted a confirmatory factor analysis (CFA) to test the measurement model. This procedure enabled us to examine convergent validity and discriminant validity of the constructs. With $\chi 2 / \mathrm{df}$ ratio of $1.86, \mathrm{CFI}=0.91$, and RMSEA $=0.06$, model fit measures seem to be satisfactory. The summary of CFA analysis is presented in Table 3 . We assessed convergent validity by examining factor loadings, composite reliability (CR), and average variance extracted (AVE). Table 3 explains that all factor loadings of the observed items on the latent constructs have a critical ratio equivalent to t-statistics ranging from 12.25 to 17.85 (all values significant at $\mathrm{p}<0.001$ ). These results are well above the critical value of 1.96 , indicating good definitions of the underlying factors (Anderson and Gerbing, 1988). Additionally, composite reliability (all values beyond the 0.7 threshold) and average variance extracted (AVE) (all values beyond the 0.5 threshold) measures support convergent validity of the scales (Bagozzi and Yi, 1988). We assessed discriminant validity of the measurement model by comparing root square of AVE with bivariate correlations. All the root square values are above 0.84 and meet the criterion of being greater than all of the bivariate correlations (Fornell and Larcker, 1981), which are presented in Table 4. We considered Cronbach's alpha for each scale in order to analyze internal consistency of latent variables. Table 4 indicates that alpha values are all above 0.85 and well beyond the threshold of 0.7 . This provides evidence for measure scale reliability (Nunnally, 1978).

We calculated a two-stage least-squares (2SLS) regression in order to address the potential for reverse causality and endogeneity - or the possibility that instead of co-creation with customers affecting managerial initiatives and managerial attention to the new technology, the prevalence of new managerial initiatives and attentiveness to a new technology could in fact be promoting co-creation. Following the procedure described by Bascle (2008), we controlled for endogeneity using instrumental variables that affect our regressor (i.e., co-creation) and thus are relevant but, at the same time, exogenous; i.e., not correlated with the error term of the structural equation. We utilized a two-item factor to measure the intrinsic motivation of employees' intrinsic motivation (Cole et al., 2012) that is crucial for interactions with customers (Osterloh

Table 3

Measurement model: parameter estimates and validity measures

\begin{tabular}{|c|c|c|c|c|}
\hline Constructs and indicators & $\begin{array}{l}\text { Standardized } \\
\text { loadings }\end{array}$ & $\begin{array}{l}\text { Critical } \\
\text { ratios }\end{array}$ & $\begin{array}{l}\text { Composite } \\
\text { reliability }\end{array}$ & AVE \\
\hline Co-creation & & & 0.95 & 0.72 \\
\hline 1. Collaboration with customers to collectively improve or develop new products/services. & 0.89 & - & & \\
\hline 2. Customers directly communicate ideas for new product/service offerings to our firm. & 0.84 & 14.77 & & \\
\hline 3. Sharing information with customers in a two-way communication. & 0.77 & 12.25 & & \\
\hline $\begin{array}{l}\text { 4. Using customers' inputs to determine which products/services should be offered/pursued } \\
\text { further by the firm. }\end{array}$ & 0.83 & 14.43 & & \\
\hline $\begin{array}{l}\text { 5. Collaboration with customers to come up with solutions to problems relating to our product } \\
\text { offerings. }\end{array}$ & 0.86 & 15.89 & & \\
\hline 6. Collaboration with customers to track changes in consumer needs, preferences and behavior. & 0.89 & 17.33 & & \\
\hline $\begin{array}{l}\text { 7. The relationship with external parties/customers has resulted in actual new/improved } \\
\text { products or services. }\end{array}$ & 0.87 & 16.24 & & \\
\hline Managerial initiatives & & & 0.94 & 0.73 \\
\hline 1. Regular changes to rules and procedures within organization. & 0.82 & - & & \\
\hline 2. Regular changes to employees' tasks and functions. & 0.82 & 13.67 & & \\
\hline 3. Regular implementation of new management systems. & 0.87 & 15.71 & & \\
\hline 4. Regular changes to the policy with regard to compensation. & 0.83 & 14.11 & & \\
\hline 5. Regular changes to the intra- and inter-departmental communication structure. & 0.89 & 16.41 & & \\
\hline 6. Regular updates to certain elements of the organizational structure. & 0.90 & 17.02 & & \\
\hline Managerial attention to Cloud & & & 0.90 & 0.76 \\
\hline 1. Cloud is not considered a strategic priority by our senior managers (Reversed). & 0.76 & - & & \\
\hline $\begin{array}{l}\text { 2. In their speeches, conversations, and other communications, our senior managers frequently } \\
\text { refer to Cloud computing as a strategic priority. }\end{array}$ & 0.91 & 16.53 & & \\
\hline $\begin{array}{l}\text { 3. We see frequent references to Cloud in our external communications (press releases, annual } \\
\text { reports, exhibitions, etc.) }\end{array}$ & 0.93 & 16.93 & & \\
\hline Exploratory behavior concerning Cloud & & & 0.95 & 0.77 \\
\hline 1. Accept demands that go beyond existing products and services. & 0.76 & - & & \\
\hline 2. Invent new products and services. & 0.84 & 14.05 & & \\
\hline 3. Utilize new opportunities in new markets. & 0.91 & 16.90 & & \\
\hline 4. Search for and approach new clients in new markets. & 0.90 & 16.23 & & \\
\hline 5. Commercialize products and services that are completely new. & 0.92 & 17.47 & & \\
\hline 6. Experiment with new products and services in our local market. & 0.93 & 17.63 & & \\
\hline Exploratory behavior concerning Cloud & & & 0.81 & 0.67 \\
\hline 1. People in the company feel energetic in their job. & 0.83 & - & & \\
\hline 2. People in the company are ready to act at any given moment & 0.81 & 7.61 & & \\
\hline
\end{tabular}


Table 5

Hierarchical regression analyses: mediating roles of managerial attention and managerial initiatives

\begin{tabular}{|c|c|c|c|c|c|c|c|c|c|}
\hline & \multicolumn{2}{|c|}{ Managerial Attention (MA) } & \multicolumn{2}{|c|}{ Managerial Initiatives (MI) } & \multicolumn{5}{|c|}{ Exploratory Innovation (EI) } \\
\hline & Model 1 & $\begin{array}{l}\text { Model } 2 \\
\mathrm{CC} \rightarrow \mathrm{MA}\end{array}$ & Model 3 & $\begin{array}{l}\text { Model } 4 \\
\text { CC } \rightarrow \text { MI }\end{array}$ & Model 5 & $\begin{array}{l}\text { Model } 6 \\
\mathrm{CC} \rightarrow \mathrm{EI}\end{array}$ & $\begin{array}{l}\text { Model } 7 \\
\mathrm{CC} \rightarrow \mathrm{MA} \rightarrow \mathrm{EI}\end{array}$ & $\begin{array}{l}\text { Model } 8 \\
\mathrm{CC} \rightarrow \mathrm{MI} \rightarrow \mathrm{EI}\end{array}$ & Model 9 \\
\hline \multicolumn{10}{|l|}{ Controls } \\
\hline 1. Size & 0.03 & 0.02 & 0.08 & 0.06 & 0.09 & 0.07 & 0.06 & 0.02 & 0.02 \\
\hline 2. Cloud provider & $0.21^{*}$ & $0.26^{*}$ & -0.06 & -0.04 & 0.12 & 0.14 & 0.05 & 0.16 & 0.13 \\
\hline 3. Cloud buyer & $-0.27^{* *}$ & $-0.39^{* *}$ & -0.04 & -0.06 & -0.11 & -0.13 & -0.00 & -0.08 & -0.04 \\
\hline 4. Cloud broker & 0.11 & 0.16 & 0.12 & 0.12 & 0.11 & 0.12 & 0.07 & 0.04 & 0.02 \\
\hline 5. Cloud enabler & 0.07 & 0.19 & 0.14 & 0.18 & 0.18 & 0.21 & 0.15 & 0.07 & 0.05 \\
\hline 6. Intrinsic motivation & $0.16^{*}$ & 0.01 & $0.23^{*}$ & 0.11 & $0.18^{*}$ & $0.10^{*}$ & 0.08 & 0.03 & 0.02 \\
\hline \multicolumn{10}{|l|}{ Variables } \\
\hline 7. Co-creation (CC) & & $0.12^{* * *}$ & & $0.31^{* * *}$ & & $0.22^{* *}$ & 0.15 & -0.02 & -0.03 \\
\hline 8. Managerial attention (MA) & & & & & & & $0.34^{* * * *}$ & & $0.12+$ \\
\hline 9. Managerial Initiatives (MI) & & & & & & & & $0.75^{* * *}$ & $0.72^{* * *}$ \\
\hline Adjusted R2 & 0.22 & 0.26 & 0.04 & 0.12 & 0.08 & 0.12 & 0.21 & 0.56 & 0.57 \\
\hline$\Delta$ Adjusted $\boldsymbol{R}^{2}$ & 0.22 & 0.04 & 0.01 & 0.08 & 0.08 & 0.04 & 0.09 & 0.44 & 0.01 \\
\hline $\mathrm{F}$ & $7.2^{* * *}$ & $7.7^{* * *}$ & 1.09 & $3.93^{* *}$ & 1.81 & $2.42^{*}$ & $3.91^{* * *}$ & $21.7^{* * *}$ & $19.8^{* * *}$ \\
\hline
\end{tabular}

Standardized coefficients are reported.

$+\rho<0.1 ;{ }^{*} \rho<0.05 ;{ }^{* *} \rho<0.01 ;{ }^{* * *} \rho<0.001$.

and Frey, 2000) and is exogenous to initiatives and the cognitive aspects of senior managers. The results of the endogeneity test using STATA 13.0 procedure did not indicate any endogeneity concern $(F=0.49$, Prob $>F=0.49)$.

Common method variance (CMV) is a potential source of bias in this study. Following the recommendations provided by Podsakoff et al., 2003), we utilized both procedural and statistical remedies to minimize such biases in our results. When designing the survey, we ensured anonymity in order to minimize evaluation and used reverse-coded scales in some of the constructs. Moreover, we controlled for single-source bias by identifying second respondents from 20 companies, and first and second respondents were compared, but no significant differences $(p<0.05)$ were found. We used Harman's single factor test to see whether most of the variance can be explained by a single common factor. We used a common latent factor (CLF) in the measurement model in order to capture the common variance among all observed variables. A latent factor was added to our AMOS CFA model, and then connected to all observed items. We compared the standardized regression weights from this model to the standardized regression weights of the original CFA model. We did not notice a large difference (no changes beyond 0.15). Hence, common method bias is not a serious concern in this survey (Podsakoff et al., 2003).

\section{Testing the hypothesized mediation effects}

Table 4 presents the descriptive statistics and correlations between the variables studied. Table 5 shows the results of the regression analyses with exploratory innovation as the dependent variable. Eight models were specified in this analysis (see Table 4). The first, third, and fifth models include only the control variables with three different dependent variables. In models 2, 4, and 6, co-creation is included to test its direct effect on managerial attention, management innovation, and exploratory innovation respectively. In Models 7 and 8, managerial attention and management innovation are added to test their mediation effect on the relationship between co-creation and exploratory innovation. To check the potential multicollinearity in the statistical models, we computed variance inflation factors (VIF) and tolerance values to further assess

Table 4

Mean, standard deviations, and correlations

\begin{tabular}{|c|c|c|c|c|c|c|c|c|c|c|c|c|}
\hline & Mean & s. d. & 1 & 2 & 3 & 4 & 5 & 6 & 7 & 8 & 9 & \\
\hline 1. Size a & 2.18 & 1.27 & - & & & & & & & & & \\
\hline 2. Cloud provider & 0.65 & 0.48 & 0.11 & - & & & & & & & & \\
\hline 3. Cloud buyer & 0.25 & 0.43 & 0.04 & -0.21 & - & & & & & & & \\
\hline 4. Cloud broker & 0.14 & 0.35 & 0.02 & -0.49 & -0.16 & - & & & & & & \\
\hline 5. Cloud enabler/consultant & 0.20 & 0.40 & 0.06 & 0.10 & 0.38 & -0.13 & - & & & & & \\
\hline 6. Customer co-creation & 4.06 & 0.59 & 0.02 & -0.08 & 0.08 & 0.00 & -0.12 & $(0.89)$ & & & & \\
\hline 7. Managerial attention & 4.13 & 0.90 & 0.04 & 0.26 & -0.44 & 0.08 & -0.01 & 0.18 & $(0.85)$ & & & \\
\hline 8. Managerial initiatives & 3.42 & 0.97 & 0.05 & -0.10 & 0.03 & 0.11 & 0.09 & 0.34 & 0.29 & $(0.91)$ & & \\
\hline 9. Exploratory innovation & 3.76 & 0.93 & 0.06 & 0.09 & -0.08 & 0.03 & 0.11 & 0.21 & 0.37 & 0.74 & $(0.94)$ & \\
\hline 10. Intrinsic motivation & 3.98 & 0.66 & -0.16 & 0.04 & 0.05 & -0.11 & -0.04 & 0.36 & 0.18 & 0.11 & 0.15 & $(0.74)$ \\
\hline
\end{tabular}

$\mathrm{n}=131$. Cronbach's alpha coefficients on the diagonal.

Logarithm of the number of full-time employees.

All correlations above 0.25 are significant at the 0.01 level (two tailed). 


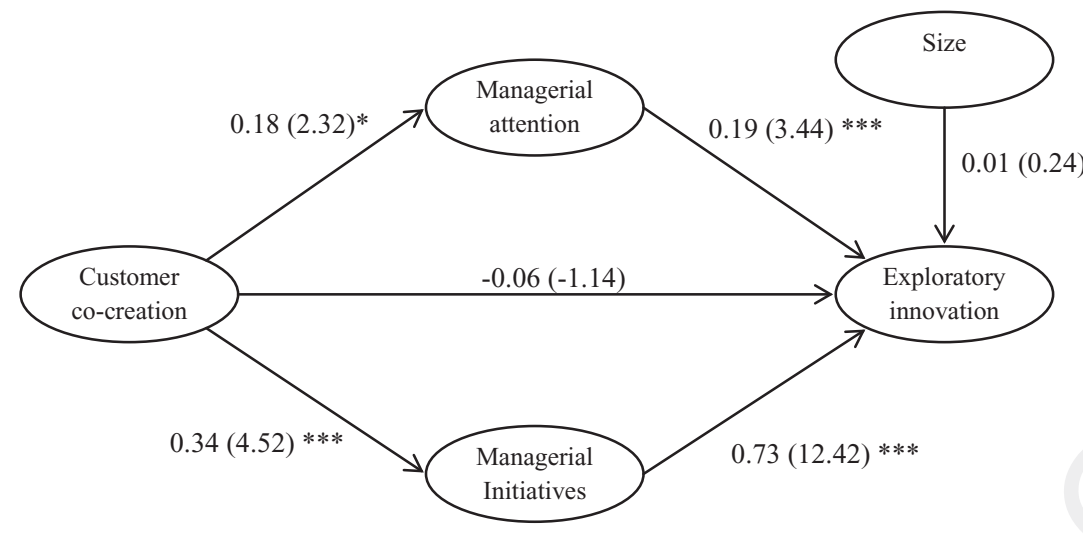

$\mathrm{t}$-values are given in parentheses

* Significant at 5\%,** Significant at $1 \%$, and $* * *$ Significant at $0.1 \%$; two-tailed t-test

Figure 2. Results of structural equations analysis

whether multicollinearity was a concern in our sample. All values were below the cut-off VIF value of 3 and well above the tolerance values of 0.2 (Neter et al., 1990).

Models 2 and 4 confirm the necessary conditions for mediation effects that we tested with Models 7 and 8 . In Model 2, co-creation shows a significant effect on managerial attention $(\beta=0.20 ; p<0.05)$, and Model 4 indicates a similar but even stronger relationship between co-creation and management innovation $(\beta=0.44 ; p<0.001)$. In Model 6 , we test the direct relationship between co-creation and exploratory innovation and the results do not reject the positive significant relationship between the two variables $(\beta=0.35 ; \mathrm{p}<0.001)$.

In Model 7, we add managerial attention, and the results support our first hypothesis on the positive influence of managerial attention on exploratory innovation $(\beta=0.30 ; p<0.05)$. In model 8 , we include management innovation instead, and again the results indicate a strong relationship $(\beta=0.69 ; \mathrm{p}<0.001)$. Therefore, the model also supports our second hypothesis on the relationship between management innovation and exploratory innovation.

Furthermore, Models 7 and 8 show that the relationship between co-creation and exploratory innovation is mediated by managerial attention and management innovation. Hierarchical regression analysis (Baron and Kenny, 1986) was used to test the potential mediation effects. In the first step, we test the direct effect by regressing co-creation on exploratory innovation (Table 3, Model 6). In the second step, the mediator management innovation is added to determine whether it mediates the previous significant relationship (Table 3, Model 3). After adding managerial attention, the standardized coefficient and the significance level of the relationship between co-creation and exploratory innovation drop from $\beta=0.35$ and $\mathrm{p}<0.001$ to $\beta=0.29$ and $\mathrm{p}<0.05$. This indicates a partial mediation effect for managerial attention on the co-creation-exploratory innovation relationship and supports Hypothesis 3. Similarly, when management innovation is added to the model, the relationship between co-creation and exploratory innovation is no longer found to be significant, although results do show that management innovation is significantly related to exploratory innovation $(\beta=0.69$; $\mathrm{p}<0.001)$ and support Hypothesis 4 . In addition, the change in adjusted R-square is quite high and statistically significant ( $\Delta$ Adjusted $\mathrm{R} 2=0.06$ and 0.39 in models 7 and 8 , both at $\rho<0.001$ ). This indicates that the first two conditions needed for a mediation effect, as identified by Baron and Kenny (1986), are met. Also the last condition needed for mediation is present in our model, since co-creation is significantly related to exploratory innovation. This means that Hypothesis 3 , which posited that management innovation fully mediates the relation between co-creation and exploratory innovation, is also supported.

\section{Post-hoc analysis}

Despite the advantage of ordinary least square regression over structural equation modeling (SEM) in that it allows the inclusion of multiple control and dummy variables (Fletcher et al., 2006), SEM has some advantages when testing the complex mediation relationships that are central to this research. Hence, in order to ensure the robustness of our findings from the regression analysis and also to verify the concurrent mediation effects of managerial attention and management innovation, we built and ran a structural equation model using AMOS 20. Figure 2 illustrates the effect sizes for the estimated path, with $\mathrm{t}$-values in parentheses.

The figures on the path are consistent with the findings from the regression analysis in confirming the first and second hypotheses on the direct relationship between managerial attention and management innovation using the measure for 
exploratory innovation. The direct link between co-creation and exploratory innovation is not significant ( $t$-value of -1.14 ) and, hence, it does not support a possible direct effect of co-creation on exploratory innovation in the organizations. Cocreation, however, significantly influences both managerial attention ( $t$-value of 2.32) and management innovation ( $t$ value of 4.52), which in turn influence exploratory innovation. We tested the proposed mediation effect with a bootstrapping algorithm in AMOS and with 2000 bootstrap samples and 95\% bias-corrected confidence intervals, and the results indicate that the mediated effect of co-creation on exploratory innovation is significantly different from zero at the 0.001 level $(\mathrm{p}=0.001$ two-tailed). We checked for model fit measures, and with GFI of 0.98, NFI of 0.95, and CFI of 0.97 the model indicates a very good fit. Given the sample size $(\mathrm{N}<250)$, the RMSEA $(0.09)$ and CMIN/df $(2.25)$ values are also reasonably low (Hu and Bentler, 1999).

Mediation can also be verified by means of the Preacher and Hayes (2004) method. This procedure makes no assumptions regarding the underlying sampling distributions and is particularly recommended for testing indirect effects when the sample size is small (Shrout and Bolger, 2002). The formal test for mediation involves calculating confidence intervals for indirect effects using bootstrapping method, and if zero falls outside of the 95 percent interval, the indirect effect is significant and one can conclude that mediation has happened. We used PROCESS SPSS add-on and the codes provided for multiple mediations with mediators operating in parallel. We resampled 1,000 times and recorded the outcomes. This approach provided results that were consistent with those obtained from the mediation analysis. In particular, zero fell outside the confidence interval around the indirect effects for managerial initiatives (effect size $=0.39$ ) and managerial attention (Effect size $=0.04$ ). These outcomes provide additional evidence that, in line with our hypotheses, managerial initiatives and management innovation mediate between customer co-creation and exploratory behavior in response to the emergence of Cloud technology.

\section{Discussion and conclusion}

In this paper, we sought to gain insight into the sources of competitiveness of organizations when confronted with a revolutionary technological change. Central arguments of this paper revolved around the role of managerial initiatives and their attention to a particular technology. Our discussions highlighted that an effective response to emerging technologies, requires attention of senior managers to the emerging technology as well as a wide range of managerial initiatives in different aspects of the organization. Managerial attention is required to secure allocation of sufficient cross-unit resources to work on the new technology and to increase the organizational members' willingness to experiment and learn in an uncertain field of knowledge. Managerial initiatives are needed for enabling an outward looking and experimental process of learning without damaging ongoing efficiency oriented activities of the organization. We provided theoretical discussions and empirical evidence that suggest customer co-creation is a potential means for increasing both senior managers' attentiveness to the consequences of emerging technologies as well as overall organizational ability for introducing the required managerial initiatives that underlie exploratory behavior in an emerging technology field.

The research findings have important implications for scholars with an interest in the effect customer orientation and co-creation strategies have on the innovative capability of organizations. Although previous research has shown cocreation to play a role in extending knowledge search and enhancing the ability of organizations to adapt to change, conflicting evidence has also led some scholars to argue that customer orientation may hinder radical innovations, as too much attention is paid to satisfying customer requests and technological change is neglected. Our theoretical discussions and empirical evidence did not point towards a direct relationship between co-creation and exploratory orientation. However, we hypothesized a possible indirect link between co-creation and exploratory behavior, and uncovered strong empirical support for this link. Our findings suggest that managers in customer-oriented organizations tend to be better at recognizing the importance of a fundamental change and at adapting their organizations so they can overcome the constraints of existing knowledge, rigid routines, and financial dependencies. According to our findings, customer-oriented organizations tend to be more capable of sensing opportunities associated with a major technological shift, and at the same time are more likely to have (or be able to devise) the experimental processes and structures essential for exploring the new technology. These findings resonate with a number of earlier studies that imply that customer involvement and co-creation have a positive effect on the knowledge search and boundary-spanning activities of organizations (Baker and Sinkula, 2007; Belderbos et al., 2004; Nambisan and Baron, 2010). The findings emphasize that, unlike what is being recommended by the design school, for example, competitiveness in the face of environmental change mandates "a long, difficult, and subtle process of learning" where, as contended by Mintzberg $(1990,190)$, "the real information may need to be dug out" during close interactions with customers. We have clarified this relationship, provided some empirical evidence of its existence, and revealed some important aspects of how it works.

Besides the primary contributions highlighted above, this paper offers two additional inputs to the strategy and organization research. First, it provides insights into the antecedents and outcomes of managerial dynamic capabilities for sensing and seizing opportunities. There has been a call for further research on different aspects of managerial cognitive capabilities in connection with strategic renewal (Helfat and Peteraf, 2014). Our results throw some light on the strategies that help managers to enhance the quality of their decisions when the business environment becomes highly unpredictable. Second, the paper provides some useful input to the growing body of literature on management innovation that explores the soft side of innovation; i.e., the role of non-technical factors crucial for helping companies to solve the fundamental 
problems they experience as a result of major changes in markets and technologies. This paper suggests that a strategic focus on customer-co-creation can potentially work as a source of new managerial initiatives, strategies, ideas and concepts to help companies deal with these challenges.

This study has some limitations that should be considered when interpreting the results. First, there are limitations concerning the context of the study. Studying a single business model change within a single industry has some advantages; for example, it helps to avoid the difficulty of controlling for differences across industries (Levin et al., 1987). However, it clearly creates an issue of generalizability. We expect our findings to be applicable to firms in other industries such as transportation, health, and utilities where emerging communication technologies are changing the prevailing business models. In fact, many other industries are being similarly influenced by Cloud computing, and there is therefore reason to believe that the findings from this study could be generalized to those as well. Albeit telecommunication technologies are at the forefront of game-changing innovations, the results seem to be applicable to others industries as well. For example, auto manufacturers can greatly benefit from customer co-creation (PwC, 2013) not only to enhance the product features, but also, as we argued, to enhance their organizational capabilities for recognizing the shifts in the market and overcoming the rigidities of efficiency oriented routines. Second, one may suggest different ways of measuring the key variables in this study. We attempted to increase the validity and relevance of the data by focusing on companies in the same industry, dealing with the same type of technological change, and informants with high levels of expertise on the questions that this study addresses. Nevertheless, operationalizing and measuring exploratory behavior, managerial attention, and co-creation through objective measures seems to be particularly beneficial. For example, it seems valuable to develop more accurate tools for measuring managers' attention and to increase the accuracy of measurement by carrying out longitudinal studies that involve access to data on senior management. Moreover, conducting a multi-respondent survey seems to be another way to eliminate potential bias in the results. Another important area for future studies might be to look at different types of revolutionary change or different industries to verify the importance of senior managers' cognition and initiatives as a link between cocreation and radical innovations.

Our analysis has several important managerial implications. First, our findings suggest that customer co-creation may act as leverage for breakthrough inventions. There is a general belief that customer input is often more effective for incremental, rather than radical, innovations. Indeed, the argument that customer input and involvement are unlikely to directly affect the design process of a radical product seems to be reasonable, but our findings suggest that the indirect effects of closeness to customers can be invaluable for understanding shifts in markets. Second, managers should consider that, although customer involvement in the innovation process appears to enhance the exploratory capability of an organization, unwillingness to change and adapt might completely negate the positive effects. This implies that, before deciding to involve customers in the firm's value-creation activities, managers need to ensure that they are actually in a position to set up and carry out subsequent managerial initiatives and organizational adaptations. This consideration becomes more important in situations of uncertainty, where the costs of interacting with customers become higher and, as Almirall and Casadesus-Masanell (2010) argue, may exceed the potential benefits.

\section{Uncited references}

Allen, 1977, Barr et al, 1992, Capron, Mitchell, 2009, Cohen, Levinthal, 1990, Hoffman, Ocasio, 2001, Posner, Petersen, 1990, Sosna et al, 2010, Tushman, Katz, 1980

\section{Appendix. Semi-structured interview protocol}

\section{Our commitments}

We appreciate your intention to participate in this research work. We would like to communicate our commitments to which we will comply throughout the research project and afterwards. We guarantee you the following:

1. The interview lasts a maximum of 60 minutes;

2. To participate in this survey is completely confidential. Your name and other information that could reveal your identity will not be included in the final report, nor be provided to other than researchers whose names are indicated in the first page of this protocol. Of course, a confidentiality statement can be provided;

3. This study is intended only for scientific purposes, and will not be used for commercial purposes;

4. We will email a literal, verbatim record of the interview for verification within 14 days;

5. The researchers within one month after the interview again contact you to address the potential mistakes in the interview report;

6. At the end of the study, a summary of the preliminary research will be provided to you.

7. You will also receive a copy of the final report at the end of the entire study

8. If you have any further questions regarding the study, you are free to contact the members of the research team or their supervisors. 
Questions

Background and context

1. Please describe your role as it relates to your companies' cloud activities.

2. What does Cloud mean for the players in your industry/sector? What are the influences on the organizations?

3. What are the main hindrances and challenges in the diffusion/adoption process of Cloud in your sector?

\section{Adoption process}

4. What are the considerations and motivations for adopters of Cloud solutions? Please describe the roles of different organizational actors (senior management, middle managers, and other employees).

5. What are the main challenges in the implementation process? Please describe the roles of different organizational actors (senior management, middle managers, and other employees).

6. How do organizations structure the initiatives for cloud adoption in their organizations? What are the key players in such structures?

7. What are the requirements for collaboration and information exchange when implementing Cloud offerings? What are the challenges?

Performance outcomes

8. What are the key benefits of Cloud Computing? (Possible areas are listed below)

\section{Efficiency}

Less OPEX/CAPEX

Better Internal processes

\section{Innovation}

Improvement in existing products or services

Invention of new products and services

Opening up new markets

New ways of serving customers

\section{Collaboration}

Facilitation of collaboration with other companies

Joint projects with companies from the industry

Organizational enablers of successful adoption

9. What organizational factors influence the adoption process (decision making/implementation) of Cloud computing in adopter organizations? (Possible factors are listed below)

- Centralized/decentralized decision making

- Formalized/informal processes

- Attitude towards risk taking

- Rewards/incentives for engagement with Cloud related activities

- Flexibility in management systems, processes, practices, and structures

- History of close collaboration with suppliers/partners/customers

- Attitude toward learning and experimentation

- Degree of dependence on external source of knowledge for development of products and services

10. To what extent do you use customer input to improve current products or to innovate new products.

Are the following factors present at your company to stimulate the usage of customer input to create new innovations?

- Changes in the rules, procedures, and ways of working

- Changes in functions or creation of new functions

- Changes in the employees' tasks

- New management systems (the way managers set goals and the way they try to achieve this goals)

- New compensation policies

- Changes in intra- and inter-departmental communication structure

- Changes in organizational structure

Control variables

Name:

Organization:

Department:

Function:

Experience (years):

Gender: 


\title{
To be filled by the interviewer
}

\author{
Name of interviewer: \\ Interview number: \\ Duration of interview: \\ Time: \\ Date: \\ Location:
}

\section{References}

Adner, R., Helfat, C.E., 2003. Corporate effects and dynamic managerial capabilities. Strategic Management Journal 24 (10), $1011-1025$.

Allen, T., 1977. Managing the Flow of Technology. MIT Press, Cambridge, MA.

Almirall, E., Casadesus-Masanell, R., 2010. Open versus closed innovation: a model of discovery and divergence. Academy of Management Review 35 (1), $27-47$.

Ansari, S., Reinecke, J., Spaan, A., 2014. How are practices made to vary? Managing practice adaptation in a multinational corporation. Organization Studies $35(9), 1313-1341$

Ansari, S.M., Fiss, P.C., Zajac, Z.J., 2010. Made to fit: how practices vary as they diffuse. Academy of Management Review 35 (1), 67-92.

Armbrust, M., Fox, A., Griffith, R., 2009. Above the Clouds: A Berkeley View of Cloud Computing. EECS Department. University of California, Berkeley. Technical report no. UCB/EECS-2009-28.

Augsdorfer, P., 2005. Bootlegging and path dependency. Research Policy 34 (1), 1-11.

Bahrami, H., 1996. The emerging flexible organization: perspectives from Silicon Valley. California Management Review 34 (4), 55-75.

Baker, W.E., Sinkula, J.M., 2007. Does market orientation facilitate balanced innovation programs? An organizational learning perspective. Journal of Product Innovation Management $24(4), 316-334$.

Baldwin, C., Hienerth, C., von Hippel, E., 2006. How user innovations become commercial products: a theoretical investigation and case study. Research Policy 35 (9), 1291-1313.

Barnett, M.L., 2008. An attention-based view of real options reasoning. Academy of Management Review 33, 605-628.

Baron, R.M., Kenny, D.A., 1986. The moderator-mediator variable distinction in social psychological research: conceptual, strategic, and statistical considerations. Journal of Personality and Social Psychology 51 (6), 1173-1182.

Barr, P.S., 1998. Adapting to unfamiliar environmental events: a look at the evolution of interpretation and its role in strategic change. Organization Science 9, 644-669.

Barr, P.S., Stimpert, J.L., Huff, A.S., 1992. Cognitive change, strategic action, and organizational renewal. Strategic Management Journal $13,15-36$.

Barreto, I., Patient, D.I., 2012. Toward a theory of intraorganizational attention based on desirability and feasibility factors. Strategic Management Journal 34, 687-703.

Belderbos, R., Carree, M., Lokshin, B., 2004. Cooperative R\&D and firm performance. Research Policy 33 (10), 1477-1492.

Benner, M.J., Tushman, M.L., 2003. Exploitation, exploration, and process management: the productivity dilemma revisited. Academy of Management Review 28 (2), 238-256.

Bennett, R., Cooper, R., 1979. Beyond the marketing concept. Business Horizons 22 (3), 76-83.

Berman, S., Kesterson-Townes, L., Marshall, A., Srivathsa, R., 2012. The power of cloud: driving business model innovation. IBM Global Business Services, Executive Report.

Birkinshaw, J., 2002. Managing internal R\&D networks in global firms: what sort of knowledge is involved? Long Range Planning 35 (3), $245-267$.

Birkinshaw, J., Nobel, R., Ridderstrale, J., 2002. Knowledge as a contingency variable: do the characteristics of knowledge predict organization structure? Organization Science $13(3), 274-289$.

Birkinshaw, J., Hamel, G., Mol, M.J., 2008. Management innovation. Academy of Management Review 33 (4), 825-845.

Boeker, W., 1997. Strategic change: the influence of managerial characteristics and organizational growth. Academy of Management Journal 40 (1), 152-170.

Bogers, M., Afuah, A., Bastian, B., 2010. Users as innovators: a review, critique, and future research directions. Journal of Management 36 (4), 857-875.

Boumgarden, P., Nickerson, J., Zenger, T.R., 2012. Sailing into the wind: exploring the relationships among ambidexterity, vacillation, and organizational performance. Strategic Management Journal 33 (6), 587-610.

Bowen, D.E., 1986. Managing customers as human resources in service organizations. Human Resource Management 25 (3), 371-383.

Bowen, D.E., Jones, G., 1986. Transaction cost analysis of service organization-customer exchange. Academy of Management Review 11 (2), $428-441$.

Brown, S.L., Eisenhardt, K.M., 1997. The art of continuous change: linking complexity theory and time-paced evolution in relentlessly shifting organizations. Administrative Science Quarterly 42 (1), 1-34.

Burgelman, R.A., 1994. Fading memories: a process theory of strategic business exit in dynamic environments. Administrative Science Quarterly 39, 24-56. Campbell, A., Birkinshaw, J., Morrison, A., Van Basten Batenburg, R., 2003. The future of corporate venturing. Sloan Management Review 45 (1), $30-37$.

Capron, L., Mitchell, W., 2009. Selection capability: how capability gaps and internal social frictions affect internal and external strategic renewal. Organization Science 20 (2), 294-312.

Carbonell, P., Rodríguez-Escudero, A.I., Pujari, D., 2009. Customer involvement in new service development: an examination of antecedents and outcomes. Journal of Product Innovation Management 26 (5), 536-550

Christensen, C., 1997. The Innovator's Dilemma: When New Technologies Cause Great Firms to Fail. Harvard Business School Press, Boston, MA.

Coen, C.A., Maritan, C.A., 2010. Investing in capabilities: the dynamics of resource allocation. Organization Science 22 (1), 99-117.

Cohen, W., Levinthal, D.A., 1990. Absorptive capacity: a new perspective on learning and innovation. Administrative Science Quarterly 35, 128-152.

Cole, M., Bruch, H., Vogel, B., 2012. Energy at work: a measurement validation and linkage to unit effectiveness. Journal of Organizational Behavior 33 (4), 445-467.

Cook, S., 2008. The contribution revolution. Harvard Business Review 86 (10), 60-69.

Covin, J., Slevin, D., 1989. Strategic management of small firms in hostile and benign environments. Strategic Management Journal 10 (1), $75-87$.

Creswell, J.W., 2008. Research design: qualitative, quantitative, and mixed methods approaches. Canadian Journal of University Continuing Education 35, 121-123.

Damanpour, F., 1991. Organizational innovation: a meta-analysis of effects of determinants and moderators. Academy of Management Journal 34 (3), 555-590. Danneels, E., 2003. Tight-loose coupling with customers: the enactment of customer orientation. Strategic Management Journal 24 (6), 559-576.

Day, G.S., Schoemaker, P.J.H., 2000. Avoiding the pitfalls of emerging technologies. California Management Review 42, 8-33.

Doz, Y.L., Kosonen, M., 2010. Embedding strategic agility. Long Range Planning 43 (2-3), 370-382.

Eggers, J.P., Kaplan, S., 2009. Cognition and renewal: comparing CEO and organizational effects on incumbent adaptation to technical change. Organization Science $20(2), 461-477$.

Eisenhardt, K.M., 1989. Building theories from case study research. Academy of Management Review 14 (4), 532-550.

Eisenhardt, K.M., Graebner, M.E., 2007. Theory building from cases: opportunities and challenges. Academy of Management Journal 50 (1), $25-32$.

Evans, P., Wolf, B., 2005. Collaboration rules. Harvard Business Review 83 (7-8), 96-104. 
Fey, C.F., Birkinshaw, J., 2005. External sources of knowledge, governance mode, and R\&D performance. Journal of Management 31 (4), 597-621.

Fleming, L., 2002. Finding the organizational sources of technological breakthroughs: the story of Hewlett-Packard's thermal inkjet. Industrial and Corporate Change 11 (5), 1059-1084.

Fletcher, T.D., Germano, L.M., Selgrade, K.A., 2006. On the Use of Partial Covariances in Structural Equation Modeling. Twenty-first Annual Conference of the Society for Industrial and Organizational Psychology, Dallas.

Fornell, C., Larcker, D.F., 1981. Evaluating structural equation models with unobservable variables and measurement error. Journal of Marketing Research $18(1), 39-50$.

Foss, N., Lyngsie, J., Zahra, S., 2013. The role of external knowledge sources and organizational design in the process of opportunity exploitation. Strategic Management Journal 1471 (4), 1453-1471.

Foss, N.J., Laursen, K., Pedersen, T., 2011. Linking customer interaction and innovation: the mediating role of new organizational practices. Organization Science 22 (4), 980-999.

Franke, N., Shah, S., 2003. How communities support innovative activities: an exploration of assistance and sharing among end-users. Research Policy 32 (1), 157-178.

Franke, N., Von Hippel, E., Schreier, M., 2006. Finding commercially attractive user innovations: a test of lead-user theory. Journal of Product Innovation Management 23(4), 301-315.

Frosch, R.A., 1996. The customer for R\&D is always wrong! Research-Technology Management 39 (6), 22-27.

Gebauer, H., 2011. Exploring the contribution of management innovation to the evolution of dynamic capabilities. Industrial Marketing Management 40 (8), 1238-1250.

Gerdes, J., Jr., 2003. EDGAR-Analyzer: automating the analysis of corporate data contained in the SEC's EDGAR database. Decision Support Systems 35 (1), $7-29$.

Gilbert, C., 2005. Unbundling the structure of inertia: resource versus routine rigidity. Academy of Management Journal 48 (5), $741-763$.

Grand, S., von Krogh, G., Leonard, D., Swap, W.W., 2004. Resource allocation beyond firm boundaries: a multi-level model for open source innovation. Long Range Planning 37 (6), 591-610.

Grewal, R., Lilien, G., Mallapragada, G., 2006. Location, location, location: how network embeddedness affects project success in open source systems. Management Science 52 (7), 1043-1056.

Grimpe, C., 2006. Making use of the unused: shelf warmer technologies in research and development. Technovation 26 (7), 770-774.

Gulati, R., Puranam, P., 2009. Renewal through reorganization: the value of inconsistencies between formal and informal organization. Organization Science 20 (2), 422-440

Gupta, A.K., Wilemon, D.L., 1990. Accelerating the development of technology-based new products. California Management Review 32, 24-45.

Hambrick, D.C., Quigley, T.J., 2014. Toward more accurate contextualization of the CEO effect on firm performance. Strategic Management Journal 491 (2), 473-491.

Hamilton, W.F., 1985. Corporate strategies for managing emerging technologies. Technology in Society 7 (2), $197-212$.

Helfat, C.E., Peteraf, M.A., 2014. Managerial cognitive capabilities and the microfoundations of dynamic capabilities. Strategic Management Journal.

Henderson, R.M., 1993. Underinvestment and incompetence as responses to radical innovation: evidence from the photolithographic alignment equipment industry. RAND Journal of Economics 24 (2), 248-270.

Heyden, M.L., Sidhu, J.S., Volberda, H.W., 2015. The conjoint influence of top and middle management characteristics on management innovation. Journal of Management doi:10.1177/0149206315614373.

Hienerth, C., 2006. The commercialization of user innovations: the development of the rodeo kayak industry. R\&D Management 36 (3), 273-294.

Hienerth, C., Keinz, P., Lettl, C., 2011. Exploring the nature and implementation process of user-centric business models. Long Range Planning 44 (5-6), 344-374.

Hodson, R., 2004. A meta-analysis of workplace ethnographies: race, gender, and employee attitudes and behaviors. Journal of Contemporary Ethnography $33(1), 4-38$

Hoffman, A.J., Ocasio, W., 2001. Not all events are attended equally: toward a middle-range theory of industry attention to external events. Organization Science 12 (4), 414-434.

Hu, L., Bentler, P.M., 1999. Cutoff criteria for fit indexes in covariance structure analysis: conventional criteria versus new alternatives. Structural Equation Modeling 6, 1-55.

Hurley, R.F., Hult, G.T.M., 1998. Innovation, market orientation, and organizational learning: an integration and empirical examination. Journal of Marketing $62(7), 42-54$.

Jansen, J.J.P., Van Den Bosch, F.A.J., Volberda, H.W., 2005. Managing potential and realized absorptive capacity: how do organizational antecedents matter? Academy of Management Journal 48 (6), 999-1015.

Jansen, J.J.P., Van Den Bosch, F.A.J., Volberda, H.W., 2006. Exploratory innovation, exploitative innovation, and performance: effects of organizational antecedents and environmental moderators. Management Science 52 (11), 1661-1674.

Jansen, J.J.P., Tempelaar, M.P., van den Bosch, F.A.J., Volberda, H.W., 2009. Structural differentiation and ambidexterity: the mediating role of integration mechanisms. Organization Science 20 (4), 797-811.

Joshi, A.W., Sharma, S., 2004. Customer knowledge development: antecedents and impact on new product performance. Journal of Marketing 68 (3), 47-59.

Kaplan, S., 2008. Cognition, capabilities, and incentives: assessing firm response to the fiber-optic revolution. Academy of Management Journal 51 (4), 672-695.

Kaplan, S., LaPort, K., Waller, M.J., 2013. The role of positive affectivity in team effectiveness during crises. Journal of Organizational Behavior 34 (4), $473-$ 491.

Karlsson, S., Lugn, A., 2009. Changing the World: The Story of Lars Magnus Ericsson and His Successors. Sellin \& Partner, Stockholm.

Karpen, I.O., Bove, L.L., Lukas, B.A., 2011. Linking service-dominant logic and strategic business practice: a conceptual model of a service-dominant orientation. Journal of Service Research 15 (1), 21-38.

Kim, T., Rhee, M., 2009. Exploration and exploitation: internal variety and environmental dynamism. Strategic Organization 7, 11-41.

Kogut, B., Zander, U., 1992. Knowledge of the firm, combinative capabilities, and the replication of technology. Organization Science 3, $383-397$.

Koka, B.R., Prescott, J.E., 2002. Strategic alliances as social capital: a multidimensional view. Strategic Management Journal 23 (9), $795-816$.

KPMG, 2013. KPMG Technology Innovation Survey. KPMG Consulting, London, UK.

Laursen, K., Salter, A., 2006. Open for innovation: the role of openness in explaining innovation performance among U.K. manufacturing firms. Strategic Management Journal 27 (2), 131-150.

Lavie, D., 2006. Capability reconfiguration: an analysis of incumbent responses to technological change. Academy of Management Review 31 (1), 153-174. Lavie, D., Stettner, U., Tushman, M.L., 2010. Exploration and exploitation within and across organizations. Academy of Management Annals 4 (1), 109-155. Lengnick-Hall, C.A., 1996. Customer contributions to quality: a different view of the customer-oriented firm. Academy of Management Review 21 (3), 791-824. Lettl, C., Herstatt, C., Gemuenden, H.G., 2006. Users' contributions to radical innovation: evidence from four cases in the field of medical equipment technology. R\&D Management 36 (3), 251-272.

Levin, R., Klevorick, A., Nelson, R., Winter, S., 1987. Appropriating the returns from industrial research and development. Brookings Papers on Economic Activity 3, 783-831.

Lewin, A.Y., Long, C.P., Carroll, T.N., 1999. The coevolution of new organizational forms. Organization Science 10, 535-550.

Lewin, A.Y., Massini, S., Peeters, C., 2011. Microfoundations of internal and external absorptive capacity routines. Organization Science 22 (1), 81-98.

Li, Q., Maggitti, P.G., Smith, K.G., Tesluk, P.E., Katila, R., 2013. Top management attention to innovation: the role of search selection and intensity in new product introductions. Academy of Management Journal 56 (3), 893-916.

Lüthje, C., Herstatt, C., Von Hippel, E., 2005. User-innovators and “local” information: the case of mountain biking. Research Policy 34 (6), $951-965$. 
Lynn, G.S., Morone, J.G., Paulson, A.S., 1996. Marketing and discontinuous innovation: the probe and learn process. California Management Review 38 (3), 8-37.

March, J.G., 1991. Exploration and exploitation in organizational learning. Organization Science 2, 71-87.

Maritan, C.A., 2001. Capital investment as investing in organization capabilities: an empirically grounded process model. Academy of Management Journal 44, 513-531.

Marston, S., Li, Z., Bandyopadhyay, S., Zhang, J., Ghalsasi, A., 2011. Cloud computing: the business perspective. Decision Support Systems 51, 176-189.

Maula, M., Keil, T., Zahra, S., 2012. Top management's attention to discontinuous technological change: corporate venture capital as an alert mechanism. Organizational Science 24(3), 1-22.

McGrath, R.G., 2010. Business models: a discovery driven approach. Long Range Planning 43 (2-3), 247-261.

McGrath, R.G., MacMillan, I., 2000. The Entrepreneurial Mindset: Strategies for Continuously Creating Opportunity in an Age of Uncertainty. Harvard Business School Press, Boston.

Miller, D., Friesen, P.H., 1983. Strategy-making and environment: the third link. Strategic Management Journal 4, 221-235.

Mintzberg, H., 1990. The design school: reconsidering the basic premises of strategic management. Strategic Management Journal 11 (3), 171-195.

Mol, M.J., Birkinshaw, J., 2014. The role of external involvement in the creation of management innovations. Organization Studies 35 (9), 1287-1312.

Nahapiet, J., Ghoshal, S., 1998. Social capital, intellectual capital and the organizational advantage. Academy of Management Review 23 (2), $242-266$.

Nambisan, S., 2002. Designing virtual customer environment for new product development: toward a theory. Academy of Management Review 27 (3), 392-413.

Nambisan, S., Baron, R.A., 2010. Different roles, different strokes: organizing virtual customer environments to promote two types of customer contributions. Organization Science 21 (2), 554-572.

Neter, J., Wasserman, W., Kutner, M.H., 1990. Applied Linear Statistical Models. Irwin, Homewood, IL.

Normann, R., 1977. Management for Growth. Wiley, New York.

Nunnally, J.C., 1978. Psychometric Theory, second ed. McGraw-Hill, NewYork.

Ocasio, W., 1997. Towards an attention-based view of the firm. Strategic Management Journal 18 (S1), 187-206.

O’Hern, M.S., Rindfleisch, A., 2010. Consumer co-creation: a typology and research agenda. In: Malhotra, N.K. (Ed.), Review of Marketing Research, vol. 6. Emerald Group Publishing Limited, Bingley, UK, pp. 84-106.

Osborne, J.D., Stubbart, C.I., Ramaprasad, A., 2001. Strategic groups and competitive enactment: a study of dynamic relationships between mental models and performance. Strategic Management Journal 22 (5), 435-454.

Osterloh, M., Frey, B.S., 2000. Motivation, knowledge transfer, and organizational forms. Organization Science 11 (5), 538-550

Parasuraman, A., Zeithaml, V.A., Berry, L.L., 1985. A conceptual model of service quality and its implications for future research. Journal of Marketing 49 , 41-50.

Payne, A.F., Storbacka, K., Frow, P., Knox, S., 2009. Co-creating brands: diagnosing and designing the relationship experience. Journal of Business Research $62(3), 379-389$.

Peeters, C., Massini, S., Lewin, A.Y., 2014. Sources of variation in the efficiency of adopting management innovation: the role of absorptive capacity routines, managerial attention and organizational legitimacy. Organization Studies 35 (9), 1343-1371.

Pierce, J.L., Delbecq, A.L., 1977. Organization structure, individual attitudes and innovation. Academy of Management Review 2, 27-37.

Piller, F., Walcher, D., 2006. Toolkits for idea competitions: a novel method to integrate users in new product development. R\&D Management 36 (3), $307-318$

Podsakoff, P.M., MacKenzie, S.B., Lee, J.-Y., Podsakoff, N.P., 2003. Common method biases in behavioral research: a critical review of the literature and recommended remedies. Journal of Applied Psychology 88, 879-903.

Posner, M., Petersen, S., 1990. The attention system of the human brain. Annual Review of Neuroscience 13, 25-42.

Prahalad, C.K., Ramaswamy, V., 2004a. Co-creation experiences: the next practice in value creation. Journal of Interactive Marketing 18 (3), 5-14.

Prahalad, C.K., Ramaswamy, V., 2004b. The Future of Competition. Harvard Business School Press, Boston, MA.

PwC, 2013. Looking Ahead: Driving Co-Creation in the Auto Industry. PwC Press Room.

Romanelli, E., Tushman, M., 1994. Organizational transformation as punctuated equilibrium: an empirical test. Academy of Management Journal 37, 11411166.

Rosenkopf, L., Nerkar, A., 2001. Beyond local search: boundary-spanning, exploration, and impact in the optical disk industry. Strategic Management Journal $22(4), 287-306$

Ross, J., Staw, B.M., 1993. Organizational escalation and exit: lessons from the Shoreham nuclear power plant. Academy of Management Journal 36, 701-732.

Sawhney, M., Verona, G., Prandelli, E., 2005. Collaborating to create: the Internet as a platform for customer engagement in product innovation. Journal of Interactive Marketing 19(4), 4-17.

Schnatterly, K., 2003. Increasing firm value through detection and prevention of white-collar crime. Strategic Management Journal 24 (7), 587-614.

Schreyögg, G., Sydow, J., 2011. Organizational path dependence: a process view. Organization Studies 32 (3), 321-335.

Selnes, F., Sallis, J., 2003. Promoting relationship learning. Journal of Marketing 67 (3), 80-95.

Sidhu, J.S., Volberda, H.W., Commandeur, H.R., 2004. Exploring exploration orientation and its determinants: some empirical evidence. Journal of Management Studies 41 (6), 913-932.

Siggelkow, N., 2001. Change in the presence of fit: the rise, the fall, and the renaissance of Liz Claiborne. Academy of Management Journal 44, 838-857.

Siggelkow, N., Levinthal, D.A., 2003. Temporarily divide to conquer: centralized, decentralized, and reintegrated organizational approaches to exploration and adaptation. Organization Science 14 (6), 650-669.

Siggelkow, N., Rivkin, J.W., 2006. When exploration backfires: unintended consequences of multilevel organizational search. Academy of Management Journal $49(4), 779-795$

Smith, R., 2009. Computing in the cloud. Research-Technology Management 52 (5), 65.

Smith, W.K., Tushman, M.L., 2005. Managing strategic contradictions: a top management model for managing innovation streams. Organization Science $16,522-536$.

Smith, W.K., Binns, A., Tushman, M.L., 2010. Complex business models: managing strategic paradoxes simultaneously. Long Range Planning 43 (2-3), 448-461. Soares, O.D.D., 1997. Innovation and Technology: Strategies and Policies. Kluwer Academic, Dordrecht.

Sosna, M., Trevinyo-Rodríguez, R.N., Velamuri, S.R., 2010. Business model innovation through trial-and-error learning. Long Range Planning 43 (2-3), $383-407$.

Stanley, S., Narver, J., 1998. Customer-led and market-oriented: let's not confuse the two. Strategic Management Journal 19(10), 1001-1006.

Tan, J.J., Litschert, R.J., 1994. Environment-strategy relationship and its performance implications: an empirical study of the Chinese electronics industry. Strategic Management Journal 15 (1), 1-20.

Taylor, A., Helfat, C.E., 2009. Organizational linkages for surviving technological change: complementary assets, middle management, and ambidexterity. Organization Science 20 (4), 718-739.

Teece, D.J., 2007. Explicating dynamic capabilities: the nature and microfoundations of (sustainable) enterprise performance. Strategic Management Journal 28 (13), 1319-1350.

Teece, D.J., Pisano, I.G., Shuen, A., 1997. Dynamic capabilities and strategic management. Strategic Management Journal 18, 509-533.

Tether, B., 2002. Who co-operates for innovation, and why: an empirical analysis. Research Policy 31 (6), 947-967.

Thomke, S. 2003. Experimentation Matters. Harvard Business School Press, Boston, MA.

Thomke, S., von Hippel, E., 2002. Customers as innovators: a new way to create value. Harvard Business Review 80 (4), 74-81.

Tushman, M.L., Anderson, P., 1986. Technological discontinuities and organizational environments. Administrative Science Quarterly 31 (3), 439-465.

Tushman, M.L., Katz, R., 1980. External communication and project performance: an investigation into the role of gatekeeper. Management Science 26 (11), 1071-1085. 